\title{
Zircon age of vaugnerite intrusives from the Central and Southern Vosges crystalline massif (E France): contribution to the geodynamics of the European Variscan belt
}

\author{
François Guillot ${ }^{1, *}$, Olivier Averbuch ${ }^{1}$, Michel Dubois ${ }^{2}$, Cyril Durand $^{2}$, Pierre Lanari ${ }^{3}$ \\ and Arnaud Gauthier ${ }^{2}$ \\ ${ }^{1}$ Univ. Lille, Univ. Littoral Côte d'Opale, CNRS, UMR 8187, LOG, Laboratoire d'Océanologie et de Géosciences, F-59000 Lille, France \\ ${ }^{2}$ Univ. Lille, EA4515, LGCgE, Laboratoire de Génie Civil et de géoEnvironnement, F-59655 Villeneuve-d'Ascq cedex, France \\ ${ }^{3}$ Institute of Geological Sciences, University of Bern, Baltzerstrasse 1+3, CH-3012 Bern, Switzerland
}

Received: 7 October 2019 / Accepted: 27 June 2020

\begin{abstract}
To provide a better picture of the active geodynamics along the Variscan suture zones during the late collisional stage (particularly regarding the evolution of the orogenic system towards HT conditions), we focused here on vaugnerites, which consist of mafic ultra-potassic magmatic rocks, intrusive into the granite-gneiss sequences of the Variscan Vosges crystalline massif. Those rocks, though subordinate in volume, are frequently associated with late-collisional granites. In the Central-Southern Vosges, they appear either as (1) pluton margin of the Southern Vosges Ballons granite complex or (2) composite dykes intrusive into migmatite and metamorphic sequences classically referred to as granite-gneiss unit (Central Vosges). Both types correspond to melanocratic rocks with prominent, Mg-rich, biotite and hornblende (20-40\% vol.,

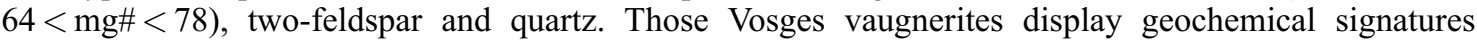
characteristic of ultra-potassic mafic to intermediate, metaluminous to slightly peraluminous rocks. Zircon $\mathrm{U}-\mathrm{Pb}$ ages were obtained by Laser Ablation Inductively Coupled Plasma Mass Spectrometry. Zircon grains were extracted from a sillimanite-bearing gneiss from the granite-gneiss unit hosting the Central Vosges vaugnerites. They yielded an age at $451 \pm 9 \mathrm{Ma}$, indicating a pre-Variscan Upper Ordovician protolith for the host sequence. Zircon from the four vaugnerite intrusives display $\mathrm{U}-\mathrm{Pb}$ ages $( \pm 2 \sigma)$ of $340 \pm 2.5 \mathrm{Ma}$ (Ballons), $340 \pm 25 \mathrm{Ma}, 340 \pm 7 \mathrm{Ma}$ and 336 $\pm 10 \mathrm{Ma}$ (Central Vosges). Synchronous within uncertainty, vaugnerite age data suggest a relatively early emplacement during the Late Variscan collisional history (i.e. Middle Visean times). These results are in line with previously published ages from the Southern Vosges volcano-sedimentary sequences (Oderen-Markstein) and the nearby ultra-potassic granite complexes from the Central and Southern Vosges (Ballons, Crêtes) thereby arguing for a magmatic event of regional significance. Recent petrological studies on vaugnerites suggest that they derive from partial melting of a metasomatized mantle contaminated to some different degrees by elements of continental crust. We propose here that the major ultra-potassic magmatic pulse at $340-335 \mathrm{Ma}$ is a consequence of a significant change into the dynamics of the Rhenohercynian subduction system below the Central-Southern Vosges. In the light of recent thermo-mechanical modelling experiments on mature continental collision, magmatism could result from a syn-collisional lithospheric delamination mechanism involving (1) first, continental subduction evolving towards (2) the underthrusting of the Avalonian continental margin lower crust and (3) the initiation of lithospheric delamination within the supra-subduction retro-wedge (SaxothuringianMoldanubian continental block). This delamination would drive the emplacement of an asthenospheric upwelling, initially localized along the Variscan suture zones, and gradually propagating towards the southern front of the belt during the Late Carboniferous, as the delamination front migrated at the base of the crust.
\end{abstract}

Keywords: Variscan orogeny / Vosges / vaugnerites / ultra-potassic magmatism / Visean / syn-collisional lithospheric delamination

\footnotetext{
* Corresponding author: francois.guillot@univ-lille.fr
} 
Résumé - Datation du zircon de vaugnérites des Vosges centrales et méridionales : contribution à la géodynamique de l'orogène varisque d'Europe. Afin d'avancer dans la compréhension de la géodynamique des zones de suture varisque au stade tardif de la collision (en particulier au regard de l'évolution du système orogénique en contexte de HT), nous nous sommes intéressés à la mise en place des vaugnérites, roches basiques ultra-potassiques intrusives au sein des ensembles granito-gneissiques de la croûte varisque des Vosges. Ces roches, souvent associées aux ensembles granitiques tardi-collisionnels, sont de faible extension mais quasiment toujours présentes au sein de ces systèmes. Elles affleurent (1) dans les Vosges méridionales, en masses plutoniques marginales du Granite des Ballons et (2) dans les Vosges centrales (région de Plainfaing), en filons composites, intrusifs dans un complexe de migmatites et de roches métamorphiques appelées granite-gneiss. Les vaugnérites sont des roches mélanocrates à biotite et hornblende magnésiennes (20 à $40 \%$ vol, $64<\mathrm{mg} \#<78$ ), présentant des signatures géochimiques caractéristiques de roches ultra-potassiques mafiques à intermédiaires, métalumineuses à légèrement peralumineuses. L'âge U-Pb obtenu par ablation laser ICP-MS du zircon d'un gneiss à sillimanite du granite-gneiss encaissant des vaugnérites est de $451 \pm 9 \mathrm{Ma}$, révélant un bâti pré-varisque à protolithe ordovicien supérieur. Les grains de zircon extraits de quatre vaugnérites donnent des âges U-Pb $( \pm 2 \sigma)$ de $340 \pm 2,5 \mathrm{Ma}$ (Ballons), $340 \pm 25 \mathrm{Ma}, 340 \pm 7 \mathrm{Ma}$ et 336 $\pm 10 \mathrm{Ma}$ (Vosges centrales). Les données de datation des vaugnérites, identiques aux incertitudes de mesure près, apparaissent donc cohérentes et révèlent un âge assez précoce dans l'histoire tardi-collisionnelle de la chaîne. Ces données, en accord avec les âges publiés préalablement sur ce secteur, montrent que les vaugnérites se mettent en place au Viséen moyen, au cours d'un événement magmatique majeur, exprimé tant dans les séries volcano-sédimentaires (Séries OderenMarkstein) que dans les granitoïdes ultra-potassiques des Vosges méridionales (Ballons) et centrales (Crêtes). Les études pétrologiques récentes sur les vaugnérites suggèrent qu'elles dérivent de la fusion partielle d'un manteau métasomatisé et contaminé à différents degrés par des éléments de croûte continentale fondue. Nous proposons ici que ce «pulse » magmatique ultra-potassique d'ampleur à 340$335 \mathrm{Ma}$ soit le signe une évolution majeure dans la dynamique de la subduction de la lithosphère rhénohercynienne sous les Vosges centrales et méridionales. Sur le modèle d'expériences thermomécaniques récentes simulant le déroulement d'une collision continentale mature, il pourrait traduire les premiers effets d'un phénomène de délamination lithosphérique syn-collisionelle impliquant (1) une subduction continentale relayée (2) par le sous-charriage d'une lame de croûte inférieure de la marge continentale avalonienne et (3) l'initiation de la délamination lithosphérique au sein du prisme orogénique supra-subduction qu'était le bloc continental saxothüringien-moldanubien. Ce processus conduirait à la mise en place d'un « upwelling » asthénosphérique, initialement localisé aux zones de suture varisque et se propageant au cours de la fin du Carbonifère vers le front sud de la chaîne à mesure de la propagation du front de délamination à la base de la croûte.

Mots clés : orogenèse varisque / Vosges / vaugnérites / magmatisme ultra-potassique / Viséen / délamination lithosphérique syn-collision

\section{Introduction}

The European Variscan orogenic belt developed during Upper Paleozoic times (i.e. Mid-Devonian-Upper Carboniferous) in response to the broad scale collision of the megacontinents Laurussia and Gondwana and the closure of intervening oceanic realms. Although studied for more than a century, the geodynamical history of this large belt still remains a matter of debate (e.g., Franke, 2006; Ballèvre et al., 2009; Faure et al., 2009; Franke et al., 2017). The subduction dynamics of involved oceanic plates and associated continental margins are still highly debated mainly due to a major late orogenic lithospheric reworking including pervasive magmatism, high temperature metamorphism and extensional deformations, that obliterated the initial collisional structure of the belt (Ledru et al., 1989; Burg et al., 1994; Costa and Rey, 1995; Faure, 1995; Gardien et al., 1997; Janousek et al., 2012; Schulmann et al., 2014). Such event, often referred to as late orogenic extensional collapse, included extensive melting of the crustal units involved in the Variscan orogenic wedge in response to a lithospheric-scale thermal imprint. Based on combined geophysical, petrological and numerical modeling arguments, this scenario was recently linked to mantle delamination below the Variscan suture zones (Schott and Schmelling, 1998; Henk et al., 2000; Gayk and Kleinschrodt, 2000; Prijac et al., 2000; Arnold et al., 2001; Ledru et al., 2001; Femenias et al., 2004; Finger et al., 2009; Averbuch and Piromallo, 2012; Laurent et al., 2017) but no integrated model is so far available.

The involvement of the mantle in this late orogenic event has been proposed, in particular, through the existence within the anatectic granitic suites of peculiar ultra-potassic mafic magmatic rocks: vaugnerite-durbachite and lamprophyre-type rocks (e.g. Gerdes et al., 2000; Bonin, 2004; Janousek and Holub, 2007; von Raumer et al., 2013; Couzinié et al., 2016; Soder and Romer, 2018; Janousek, 2019). These specific rocks, also referred to in the recent literature as $\mathrm{Mg}-\mathrm{K}$ (e.g. Tabaud et al., 2015) or Post Collisional Mafic Magmas (Couzinié et al., 2016), are characterized by magmatic assemblages with dominant dark minerals including Mg-rich biotite (phlogopiteeastonite), $\mathrm{Mg}$-rich amphibole and/or $\mathrm{Mg}$-rich pyroxene associated to various amount of plagioclase and alkali feldspars, with generally minor quartz. Due to such peculiar and variable composition, they are difficult to fit into classical 
classifications of magmatic rocks but were generally referred to, in the literature, as melasyenitic to dioritic-gabbroic type rocks (e.g. Janousek and Holub, 2007; Tabaud et al., 2015; Laurent et al., 2017). Those rocks display complex and heterogeneous petrological characters and geochemical signatures involving variable proportions of crustal and mantellic sources (e.g., Couzinié et al., 2016). Hence they received various interpretations in the past invoking either late metasomatic, or cumulative mechanisms (e.g., Montel and Weisbrod, 1986 and references herein). In more recent times, however, they have been generally considered to originate from partial melting of a metasomatized mantle, variably enriched by crustal contamination, presumably associated to former or possibly still on-going continental subduction (e.g., Sabatier, 1980; Montel and Weisbrod, 1986; Rossi, 1986; Michon, 1987; Banzet, 1987; Turpin et al., 1988; Sabatier, 1991; Foley, 1992; Holub, 1997; Debon and Lemmet, 1999; Gerdes et al., 2000; Bonin, 2004; Solgadi et al., 2007; Scarrow et al., 2008; Parat et al., 2010; von Raumer et al., 2013; Couzinié et al., 2016; Moyen et al., 2017; Laurent et al., 2017; Förster et al., 2019).

Vaugnerites appear generally as subordinate magmatic bodies but occur throughout the basement massifs cropping out along the Variscan suture zones (Fig. 1) i.e. the French Massif Central (Sabatier, 1980; Montel and Weisbrod, 1986; Michon, 1987; Barbey et al., 2015; Solgadi et al., 2007; Couzinié et al., 2014; 2016; Laurent et al., 2017), the Armorican and Cornwall massifs (Exley et al., 1983; Le Gall et al., 1989; Dupuis et al., 2015), the Vosges-Black Forest-Saxothuringian massifs (Gagny, 1978; André, 1981; Hegner et al., 1998; von Seckendorff et al., 2004b; Tabaud et al., 2014; Tabaud et al., 2015; Soder and Romer, 2018), the Bohemian massif (Holub, 1997; Gerdes et al., 2000; Seifert, 2008; Zeitlhofer et al., 2016; Kubínová et al., 2017), the External Crystalline massifs of the Western Alps and Corsica (Banzet, 1987; Bussy et al., 1998; Bonin et al., 1998; Debon et al., 1998; Rossi et al., 2009) and some Variscan massifs from Spain (Scarrow et al., 2008, 2011).

Radiogenic dating of these ultra-potassic mafic magmatic suites reveals a rather large time-span for their emplacement ranging between ca $340 \mathrm{Ma}$ to ca $265 \mathrm{Ma}$, i.e. midCarboniferous to mid-Permian (Schaltegger and Corfu, 1992; Hegner et al., 1998; Schulmann et al., 2002; von Seckendorff et al., 2004a; Scarrow et al., 2006; Seifert, 2008; von Raumer et al., 2013; Couzinié et al., 2014; Dupuis et al., 2015; Tabaud et al., 2015; Laurent et al., 2017). This large time-span might indicate the existence of superimposed magmatic pulses associated to various mantle melting events in connection with multiple Variscan collisions and orogenic root removals along successive suture zones (von Raumer et al., 2013; Skrzypek et al., 2014; Kubínová et al., 2017). Alternatively, one could advocate a single magmatic event associated to mantle upwelling, presumably due to lithospheric delamination, propagating outward from the suture zones at the end of the collision period (Laurent et al., 2017).

The time-space evolution of these late orogenic ultrapotassic mantle-derived magmatic suites is thus critical to further constrain the Variscan orogen geodynamical models and, more generally, the late evolution of collisional mountain belt at a lithospheric-asthenospheric scale. In this perspective, we focused here on some vaugnerite magmatic bodies from the Central and Southern Vosges massifs in Eastern France (Fig. 1). These bodies are associated in subordinate amounts to the Variscan basement massifs of gneiss and granite. In Southern Vosges, they occur as mafic margin of the co-genetic ultra-potassic granitoid Ballons pluton. In Central Vosges, they crop out as isolated dykes or stocks across a so-called "granitegneiss" massif. In the following, we present new results of petrological and zircon dating analyses by Laser Ablation Inductively Coupled Plasma Mass Spectrometry (LA-ICPMS) for four rock samples of vaugnerite intrusives of the Central-Southern Vosges and one of the "granite-gneiss". These results are integrated in the geodynamical evolution of the Vosges massif and, at a larger scale, of the equivalent massifs along the Variscan suture zones thereby leading to a revised lithospheric-scale geodynamical model for the late evolution of the belt.

\section{Geological setting}

The study of the geological evolution of the Vosges crystalline Massif, since the nineteenth century, has successively obeyed very diverse paradigms. Hence the prevailing ideas upon the Vosges massif endured several upheavals, their final sum being all but easy to decipher and practically impossible to summarize. Hereafter, we will present a synthesis of the most recent views but we will also refer to some older observations that proved useful.

\subsection{Outline of the geological evolution of the Variscan Vosges Massif}

The Vosges crystalline massif (Eastern France) and its homolog in Western Germany, the Black Forest Massif (Fig. 1), have been exhumed in Tertiary times as the uplifted shoulders of the Rhine graben (e.g. Bourgeois et al., 2007 and references herein). The Vosges mountains exhibit metamorphic and magmatic Paleozoic rocks juxtaposed during the Variscan orogenic cycle as the result of superimposed nappe stacking, extensional detachment and transcurrent faulting with synchronous volcanism and granitoid intrusions (Fluck et al., 1989; Edel and Fluck, 1989; Eisbacher et al., 1989; Rey et al., 1991; Piqué et al., 1994; Lardeaux et al., 2014; Skrzypek et al., 2014; Tabaud et al., 2014, 2015). This resulted in a complex structural pattern and rather contrasted exhumation pathways as exemplified by the main tectonic boundary across the massif i.e. the Lalaye-Lubine Fault Zone (LLFZ, Figs. 1 and 2).

The Lalaye-Lubine Fault Zone separates the low-grade Lower Paleozoic meta-sedimentary rocks of the Northern Vosges domain (Piqué et al., 1994; Skrzypek et al., 2014) from the HP-HT Eclogite-Granulite-Migmatite complex of the Central Vosges (Fluck, 1980; Rey et al., 1989; Latouche et al., 1992; Altherr and Kalt, 1996; Skrzypek et al., 2012b; Altherr and Soder, 2018). Despite polyphase reworking of its initial structure, it was generally considered to localize the MidUpper Devonian (ca. 380 Ma) early Variscan suture zone between the Northern Saxothuringian and the Southern Moldanubian domains (Fig. 1) (Wickert and Eisbacher, 1988; Fluck et al., 1989; Edel and Fluck, 1989; Rey et al., 1991; Piqué et al., 1994; Franke, 2000). Based on a Bohemian 


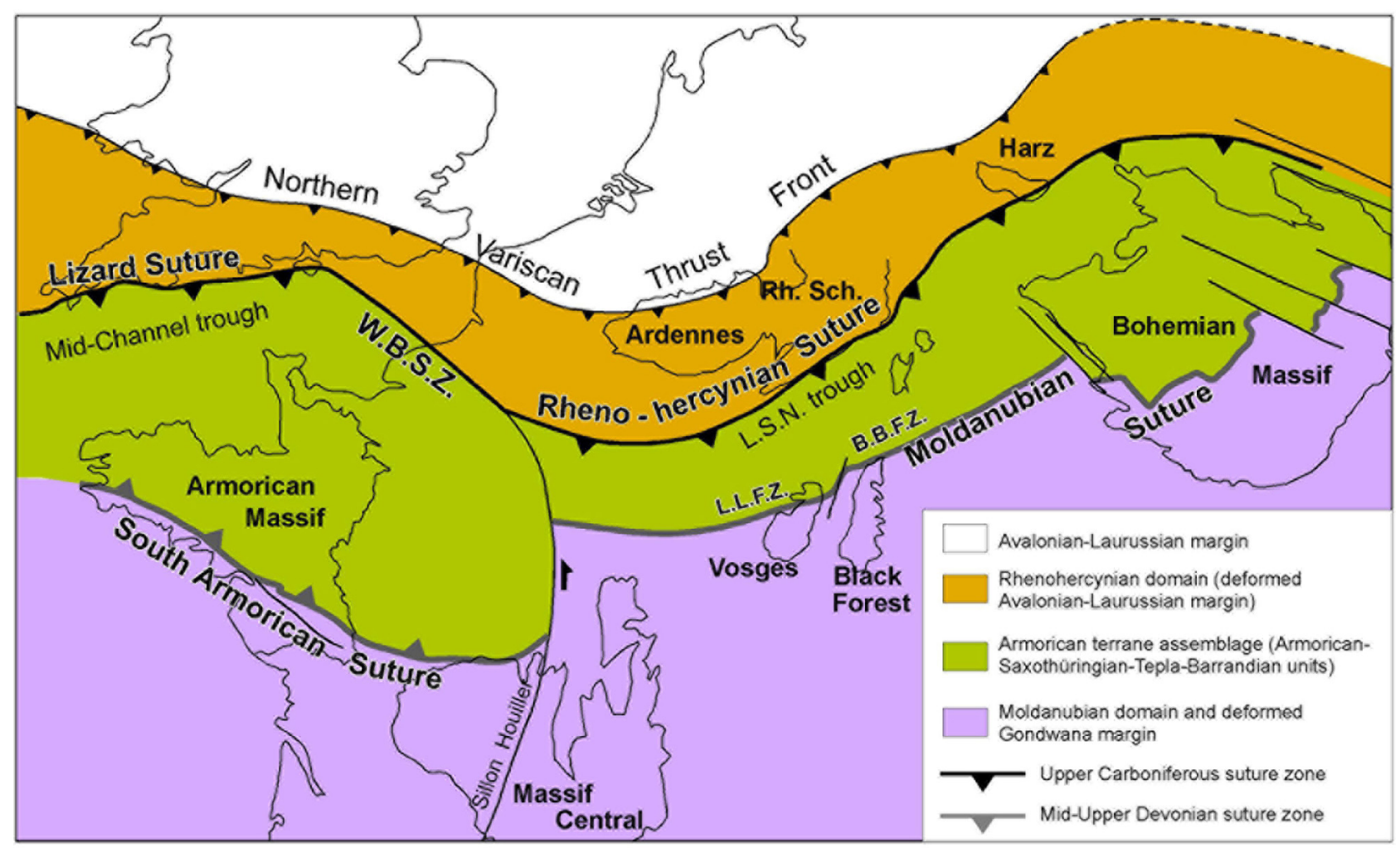

Fig. 1. General geodynamical framework of the Variscan belt in Western and Central Europe (chiefly based on the map of Edel et al., 2013). LLFZ: Lalaye-Lubine fault zone; BBFZ: Baden-Baden fault zone; L.S.N.: Lorraine-Sarre-Nahe; W.B.S.Z.: Isle-of-Wight-Bray suture zone; Rh. Sch: Rhenish Slate Massif.

massif analogy, some slightly different views have been proposed recently by Skrzypek et al. (2014) suggesting the amalgamation of the Saxothuringian-Tepla-Barrandian-Moldanubian domains within a very restricted area bordering to the North the Lalaye-Lubine dislocation. Those contrasting interpretations have some important consequences on the inferred vergence of the associated subducted slabs and NWas well as SE-dipping slabs have been considered depending on the way this major northern Vosges tectonic boundary is connected laterally to adjacent suture zones (e.g. Matte, 2001; Franke, 2006; Ballèvre et al., 2009; Edel et al., 2013; Lardeaux et al., 2014; Skrzypek et al., 2014; Franke et al., 2017). Whatever the precise location of this suture zone, as observed throughout the internal zones of the belt (i.e. South Armorican domain, Massif central, Bohemian massif), this early collisional phase is marked by widespread remnants of HP and UHP rocks buried during continental subduction and then partly melted or affected by a significant HT metamorphic imprint during their exhumation (Matte, 1998; Lardeaux et al., 2001; Faure et al., 2008; Ballèvre et al., 2009; Faryad and Kachlyk, 2013; Lardeaux et al., 2014).

The subsequent Carboniferous evolution of the Vosges massif is dominantly controlled by its localization in a suprasubduction position with regards to the south-directed Rhenohercynian subducted slab (Fig. 1) (Skrzypek et al., 2012a; Edel et al., 2013). Such evolution is particularly well exemplified in the Northern Vosges units (i.e. north of the Lalaye-Lubine Fault Zone, LLFZ) where a long-lasting calc-alkaline activity evidences a magmatic arc throughout the Carboniferous (Piqué et al., 1994; Altherr et al., 2000; Tabaud et al., 2014), interpreted as the western prolongation of the Saxothuringian Mid-German Crystalline Rise (Oncken, 1997; Skrzypek et al., 2014). This Northern Vosges magmatism evolved from arc-type calc-alkaline (c. $335 \mathrm{Ma}$ ) to high-K calc-alkaline (c. 325-320 Ma) (Tabaud et al., 2014). Peraluminous anatectic granites and ultra-potassic $(\mathrm{Mg}-\mathrm{K})$ magmatic intrusives emplaced within the Northern Vosges magmatic complex at c. 310-290 Ma (Tabaud et al., 2014) sign the thermal imprint observed throughout the Variscan suprasubduction crustal domains during the late collisional stage. This Late Variscan magmatic event also produced a wealth of effusive rocks as exemplified by the Northern Vosges Nideck volcanic system (Edel and Schneider, 1995) and the numerous volcanic layers deposited in the nearby Late Carboniferous-Early Permian Lorraine-Saar-Nahe intermontane basin (L.S.N. trough in Fig. 1) (von Seckendorff et al., 2004b). The development of highly subsiding rift basins on top and at the northern border of the Vosges basement massif (i.e. the Lorraine-Saar-Nahe (Donsimoni, 1981; Henk, 1993; Stollhofen, 1998; Edel and Schulmann, 2009) and the St Dié-Villé basins (Carasco, 1989; Durand, 2014), points to a general transition from compression to extension within the Variscan orogenic wedge, characteristic of the tectonic collapse stage. The localization of Late Carboniferous (Stephanian) molasses along the Lalaye-Lubine fault zone (Durand, 2014) suggests that the former Early Variscan SaxothuringianMoldanubian suture zone was reactivated as a normal fault during the development of the late orogenic St Dié-Villé basin as 


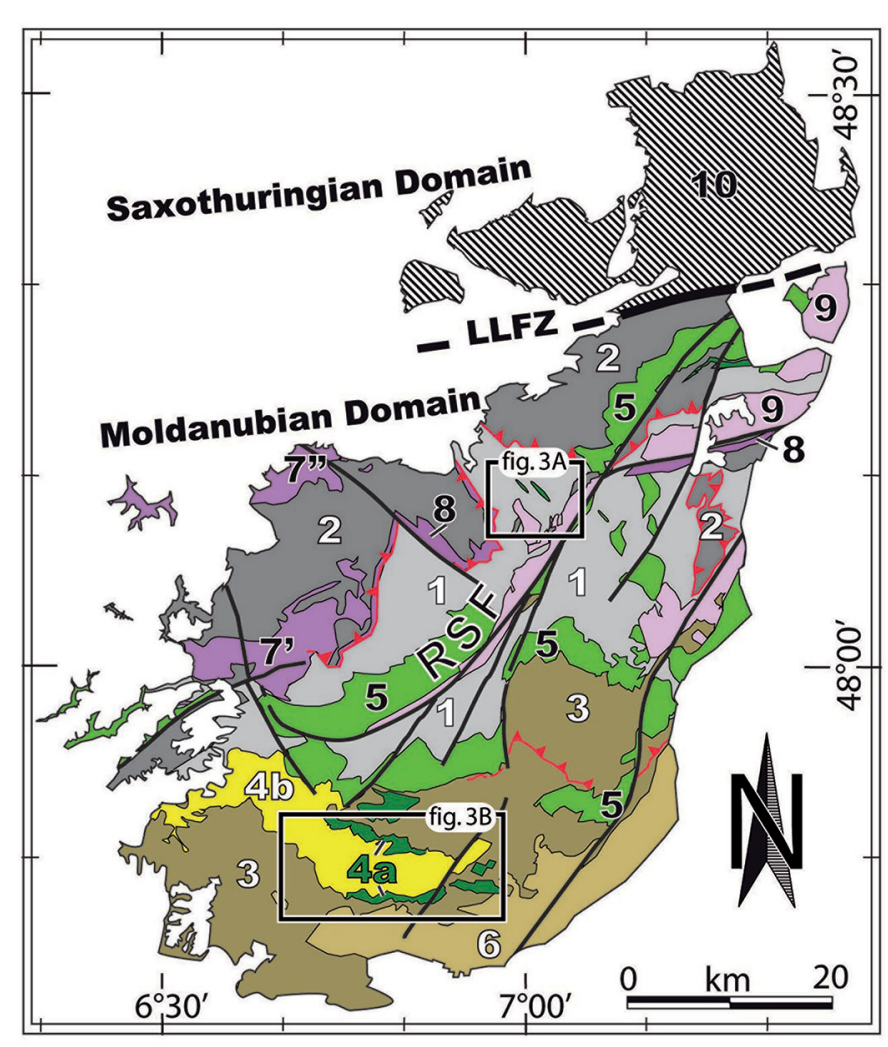

Fig. 2. Geological map of the Vosges massif, mainly after von Eller et al. (1972), Fluck et al. (1989), Ménillet et al. (1989), Skrzypek et al. (2012a, 2012b), and the present study. 1. Granite-gneiss units 2. Migmatites and granulitic gneiss \pm pods of garnet pyroxenite and eclogite. 3. Early-Middle Visean volcano-sedimentary sequences, mostly marine. 4. Mg-K granitoids, 4a: vaugnerite-durbachite, 4b: Ballons pluton monzogranite (both intruded 1 and 3). 5. Mg-K granitoids, Amp-Bt monzogranite plutons ("Granite des Crêtes", intruded 1,3). 6. Late Visean, mostly volcanic deposits, post-plutonic versus $4 \mathrm{a}, 4 \mathrm{~b}$ of which they contain reworked pebbles. $7^{\prime}, 7^{\prime \prime}$. resp. Remiremont Granite, Epinal Granite. 8. Straiture and Bilstein syntectonic granite. 9. Late-tectonic, Upper Carboniferous leucogranites. 10.- Northern Vosges, undifferentiated (see text). RSF. - Retournemer- Sainte-Marie-aux-Mines Fault. LLFZ. - LalayeLubine Fault Zone.

also observed in the Rhenohercynian suture zone at the northern border of the Lorraine-Sarre-Nahe basin (Oncken et al., 2000; Averbuch and Piromallo, 2012). This scenario was also proposed by Skrzypek et al. (2014) as this major boundary was interpreted as a significant detachment fault active during the late evolution of the belt.

The Vosges units south of Lalaye-Lubine fault zone (i.e. the classically called Moldanubian Vosges) (Fig. 2) should have experienced roughly the same evolution during Carboniferous times as no remaining oceanic realm is considered to exist between the northern and central Vosgian blocks at that time. Such interpretation is also suggested by the magmatic affinity trends recorded within the Lower Carboniferous volcanic sequences interlayered within the Southern Vosges volcano-sedimentary basin i.e. arc-tholeiites-calc-alkaline to high-K calc-alkaline to shoshonitic affinities (Lefèvre et al.,
1994; Lakhrissi, 1996; Eisele et al., 2000). The volcanic activity was restricted to a narrow range of $5 \mathrm{Ma}$ at c. 345 $340 \mathrm{Ma}$ (Schaltegger et al., 1996) but this age pattern appears in contradiction with proposed stratigraphic ages (up to ca $330 \mathrm{Ma}$ ) of foraminifera included in associated limestone turbidites (Montenari, 1999; Franke, 2000) thereby suggesting reworking of volcanic layers. As shown by detailed mapping (e.g. Ménillet et al., 1989, and references therein), these effusive sequences were co-magmatic with the hosted Ballons plutonic complex $(4 \mathrm{a}+4 \mathrm{~b}$ in Fig. 2$)$, which also displays an ultra-potassic (shoshonitic) pattern (Pagel and Leterrier, 1980). These data are in line with the view that, during Carboniferous times, the Northern and Central-Southern Vosges evolved as a coherent crustal domain (Fluck, 1980; Boutin et al., 1995) submitted to the main influence of the underlying Rhenohercynian subduction (Eisele et al., 2000). Skrzypek et al. (2014) and Tabaud et al. (2015) proposed an alternative geodynamical model including some residual decoupling between the Northern and Central Vosges associated to the subducted (i.e. Upper Devonian) Saxothuringian continental slab controlling the Central and Southern Vosges magmatism (considered as overall ultra-potassic (Mg-K) associations) through relamination below the Moldanubian lithosphere. Such debated Central-Southern Vosges magmatic events are further discussed in the following sections.

As previously mentioned, the kinematics of deformation during Carboniferous of the Vosges and Black Forest massifs involves superimposed extensional and compressional events (Eisbacher et al., 1989; Echtler and Chauvet, 1992; Rey et al., 1991), difficult to resolve in space and time. The upper plate of the Rhenohercynian subduction, the formerly thickened lithosphere of the Vosges, is likely to have experienced compressional and extensional deformation in relation with the internal slab dynamics i.e. coupling versus decoupling conditions at the trench (e.g., Guillaume et al., 2009). The development of the Southern Vosges volcano-sedimentary basin during latest Devonian-Middle Visean times (e.g., Schneider, 1990) argues however for a long-term subsidence of the lithosphere coeval with the development of the magmatic arc of the Northern Vosges. This strongly supports a first-order back-arc extensional (or at least transtensional) context of the supra-subduction Southern Vosges crustal domain during most of Carboniferous times up to mid-Visean times (Schaltegger et al., 1996; Eisele et al., 2000; Schulmann et al., 2002).

The subsequent involvement of the Lower Carboniferous volcano-sedimentary complex into South-verging thrusts (the Southern Vosges Klippen Belt: Fluck et al., 1989; Skrzypek et al., 2012a) as well as the evolution from marine turbidites to continental molasses within the Southern Vosges basin (Eisele et al., 2000) points to a transition towards a compressional environment, very likely from Middle Visean times ca. $340 \mathrm{Ma}$ onward (Petrini and Burg, 1998; Schulmann et al., 2002). Coeval southward thrusting and induced mylonitic deformation are also recorded in orthogneisses from the Southern Black Forest (Echtler and Chauvet, 1992; Chen et al., 2003; Vaida et al., 2004) thereby confirming an overall compressional setting within the upper plate of the Rhenohercynian subduction. Such deformations likely generated a largerscale Saxothuringian retro-wedge (Schäfer et al., 2000). 
As suggested by Schäfer et al. (2000) and supported by analogue modeling experiments (Hoth et al., 2008), this transfer of shortening backward into the upper plate by MidUpper Carboniferous times was kinematically coupled to the Rhenohercynian pro-wedge characterized by the deposition within its foredeep of Visean turbidites grading upward into Namurian-Westphalian molasses (Ricken et al., 2000). Such pervasive orogenic markers are likely to mark the onset of the collision. It is possible that mantle peridotite slivers were incorporated at the base of the crust during this incipient collision as suggested by garnet-peridotite lenses included in the granulite-migmatite complexes of the Central Vosges at c. 340-335 Ma (Gayk and Kleinschrodt, 2000). The very fast velocities required for their exhumation are suggested to result from the final late-orogenic tectonic collapse event (Gayk and Kleinschrodt, 2000) that reworked thoroughly the primary collisional structure through the development of crustal-scale extensional detachments (Rey et al., 1991; Echtler and Chauvet, 1992; Skrzypek et al., 2014) and pervasive crustal melting (Tabaud et al., 2014, 2015).

\subsection{Outcrop-scale observations and sampling}

The vaugnerites were sampled in the Central-Southern Vosges crystalline complex referred to as the Moldanubian Vosges units. This unit exhibits two main subdomains, from $\mathrm{N}$ to $\mathrm{S}$ :

- a gneiss-granulite belt (i.e. the sensu stricto Moldanubian metamorphic units; Rey et al., 1991; Latouche et al., 1992) that some authors recently divided into a felsic granulite and varied/monotonous gneiss units based on a Bohemian massif perspective (Skrzypek et al., 2014) but that was also assigned previously to the "Leptyno-Amphibolite" complex of the French Massif central (Fluck et al., 1989; Lardeaux et al., 2014);

- a Late Devonian-Lower Carboniferous volcano-sedimentary basin filled by mainly marine turbidites grading upward into continental molasses at the top of the clastic sequence (Fluck et al., 1989; Schneider, 1990; Skrzypek et al., 2014).

Voluminous ultra-potassic plutons defined as Mg-K type following Tabaud et al. (2015) or KCG type (high-K Calcalkaline Granites) following Barbarin (1999) as well as anatectic granites were emplaced across those two subdomains (Fig. 2; see the recent synthesis of Tabaud et al., 2015 for a description of the various magmatic suites). Some major venues of the ultra-potassic mantle-derived magmas intruded along, or branched upon, the nearly-vertical RetournemerSainte-Marie-aux-Mines NE-SW-striking shear zone (RSF in Figs. 2 and $3 \mathrm{~A}$ ). The RSF syn-kinematic granite band, referred to as Granite des Crêtes and emplaced at ca $337 \mathrm{Ma}$ (Tabaud et al., 2015), offsets sinistrally the Central Vosges granitegneiss and migmatites-granulite and bounds the fossiliferous volcano-sedimentary units of the Southern Vosges intruded by the Ballons granite complex. It is worth noting that numerous lamprophyre dykes are present across the Central and Southern Vosges units (Soder and Romer, 2018), very likely associated to the vaugnerite intrusions and the ultra-potassic Crêtes and Ballons granitoid complexes. Age data are lacking to provide a precise view of the dynamics of this major late-orogenic ultra-potassic magmatic event.

Three vaugnerite outcrops from Central Vosges were sampled near the Clefcy, Barançon and Habeaurupt villages (samples Vo15-01, Vo15-04 and Vo15-07, resp., in Fig. 3A). The vaugnerites were mapped (Ménillet et al., 1978) as NWSE trending, nearly vertical bodies, featuring dykes within host formations referred to as the granite-gneiss complex (GGC). The contacts of the vaugnerites with this host-rock are scarcely observable, adding some uncertainty to the chronology of the metamorphic/magmatic events.

Delesse (1851) first gave a mineralogical description and a chemical analysis of the Clefcy vaugnerite, that he reported as a "micaceous diorite" embedded in "the" granite and cut by reddish-white, cm-thick granite veins (Fig. 4A, D). He described transitional contacts with the host, reddish or pink granite. Indeed, from what we observed at Habeaurupt and at Clefcy, those reddish granites do not present any foliation, alike the vaugnerite itself. By contrast, the nearby granite-gneiss is foliated (Fig. 4C) and experienced a solid-state deformation before the emplacement of the vaugnerite. The reddish or pink veins (Fig. 4A, and lower part of Fig. 4D) might rather be viewed as co-magmatic to the vaugnerite, both being magmatically emplaced later than the solid-state deformation of their hostGGC. The close association of vaugnerite with synchronous leucosome was also described by Couzinié et al. (2014) in the Velay orthogneiss (French Massif Central) and interpreted as magmatic intrusion in a partially molten host.

History of $G G C$ interpretations. The granite-gneiss complex (GGC), defined by German authors during the nineteenth century, was long considered as a Precambrian sedimentary sequence "granitized" during supposedly Caledonian events ("granite fondamental" for Hameurt, 1966; Camboly, 1966; Camboly et al., 1967; Ménillet et al., 1978). Those authors, relying upon a model called "zonéographie du métamorphisme" (Jung and Roques, 1952) that invoked pervasive and strong metasomatic effects as the major graniteforming mechanism (analog of palingenesis elsewhere, as recalled by Sawyer, 2008), assumed that the vaugnerites were primitively basaltic sills, secondarily granitized and "feldspathized" together with their host-rock, itself viewed as a granitized grauwacke series. In fact, such an explanation can be easily discarded for the vaugnerites considering their normal order of crystallization (Ap-Hbl-Bt-Pl + Kfs-Qz), where biotite is euhedral, magmatic and obviously not a secondary mineral (see Figs. 4 and 5 for thin section images). The extant Gérardmer sheet at 1/50,000 scale, edited by the French Geological Survey (Ménillet et al., 1978), was probably a source of confusion, exposing initially biased interpretations of the GGC. Blumenfeld and Bouchez (1988) instead called the GGC "Axial Unit (granitic and gneissic formations)". Fluck et al. (1989) divided the GGC into three formations: "biotite or two-mica anatectic granites of the basement", "anatectic granites of the Devono-Dinantian cover" and "Crêtes Granite". Rey et al. (1991) rather distinguished "undeformed granite" and "solid-state deformed granite" out of the GGC, with no clear reference to the previously published maps. In recent times, the GGC was generally referred to as "anatectic granite", designation indeed somewhat simplified regarding the heterogeneity of this rock complex (Schaltegger et al., 1999; Kratinová et al., 2007; 



Fig. 3. Geological context of the dated samples. - A. Geological context of Central Vosges samples after maps (Hameurt, 1966; von Eller et al., 1970; Ménillet et al., 1978) merged and redrawn using results from the present work. Background digital elevation map from GeoMapApp.org, with illumination from NW. RSF, see Fig. 2. 1: Bt-Sil Granite-Gneiss main body. 2: Andalusite Granite-Gneiss. 3: Bi-Act Granite-Gneiss and "Granite Fondamental", anatectic bodies. 4: cloudy, Grt-Crd "Gneiss Perlé” granulitic migmatite. 5: porphyritic, Hbl-Bt monzogranite ("Granite des Crêtes"). 6: porphyritic leucogranite (Vic leucogranite and Valtin two-mica granite). 7: syn-thrusting Straiture Granite. 8: vaugnerite dyke. 9: microgranite dyke. 10: Quaternary river deposit. 11: major fault. 12: sample for geochronology (this paper). 13: sample GG4 from Tabaud et al. (2015) - see text for discussion. - B. Geological map of Southern Vosges vaugnerites and explanatory cross-sectional sketch (not to scale), redrawn and oversimplified after André (1983), Ménillet et al. (1989), Théobald et al. (1974); background digital elevation map from GeoMapApp.org, illuminated from NW. 1: Devonian to Early Visean deposits. 2: Early-Middle Visean volcanics and intrusives. 3: syenite, vaugnerite, monzonite and gabbro. 4: Ballons monzonitic, KF-porphyric, cpx-bio granite. 5: Late Visean, mainly volcanic deposits. Location of rocks dated by U-Pb on zircon: Vo15-08: LA-ICP-MS, this study. $a$ : $340+4 /-2 \mathrm{Ma}$, and $b+c: 342 \pm 1$ Ma, ID-TIMS by Schaltegger et al. (1995); $d$ : $336.3 \pm 3.5 \mathrm{Ma}$ (sample BA11), e: 345.5 $\pm 2.2 \mathrm{Ma}$ (sample BAB5), and $f: 345.3 \pm 2.5 \mathrm{Ma}$ (BAB4): LA-ICP-MS by Tabaud et al. (2015). Named places: S, Sewen; BA, Ballon d'Alsace; SM, St-Maurice-sur-Moselle; SV, Servance; CL, Château-Lambert.

Schulmann et al., 2002). The most recent tectonic-metamorphic-magmatic studies on the Vosges Variscan massif (Skrzypek et al., 2014; Lardeaux et al., 2014; Tabaud et al., 2015) adopted this general view, the GGC complex being simply defined as "Central Vosges Granite" of anatectic origin, admitting the strongly heterogeneous character of this unit with weakly foliated parts and relicts of para- and orthogneisses. To better constrain the dynamics of the GGC, the granite-gneiss sequence hosting the vaugnerites was sampled at La Grande Roche (Vo14-16, loc. in Fig. 3A). The foliation planes of this leucocratic, biotite-spotted gneiss (Fig. 4C) have a violet luster, usual in sillimanite-bearing rocks.

One vaugnerite was sampled in the Southern Vosges, near the Tête des Sapins at the northern border of the Ballons granite (loc. in Fig. 3B: Vo15-08). It belongs to mafic plutonic sub-units of diorite to vaugnerite occurring on the margins of the main Ballons granite pluton. Their contact with the granite was detailed by André and Gagny (1981), André and Bébien (1983a, 1983b) and André (1983). The magmatic brecciation of vaugnerite by granite attests to the anteriority of the vaugnerite upon the granite. The same authors proposed that the 


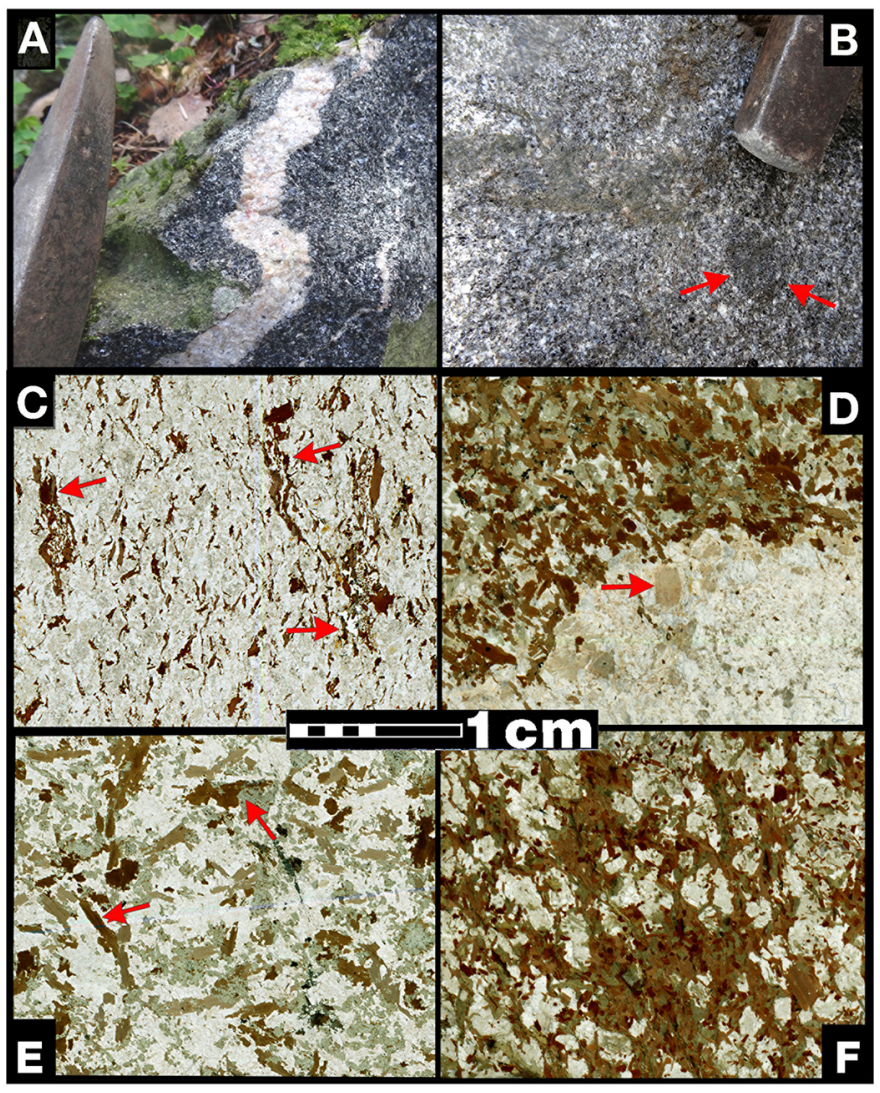

Fig. 4. Texture of the dated rocks, outcrop pattern (A, B) and scanned thin sections ( $\mathrm{C}$ to $\mathrm{F})$. - A, Clefcy quarry dark vaugnerite with pink, light syenite vein and veinlet. Hammer-pick for scale. - B, Habeaurupt vaugnerite with transitional contact between a leucocratic type (left) and a mesocratic type (right), with a darker enclave (arrows). Hammer-head for scale. - $\mathrm{C}$, granite-gneiss, relatively fine-grained, its foliation marked by sub-parallel, elongated and sinuous biotite sections (arrows). — D, Clefcy melanocratic vaugnerite (top: $\mathrm{Bt} \sim 40 \% \mathrm{Amp} 30 \%$ ) and a biotite-free vein of pink syenite-granite, its color due to hematite dust in albite phenocrysts (arrow). - E, Barançon vaugnerite, characterized by its oversized biotite crystals (arrows) even in this mesocratic type, with green amphibole \pm chlorite. - F, Habeaurupt vaugnerite, biotitedominated, melanocratic type.

vaugnerite might be sub-contemporaneous with the adjoining Visean volcanics, while the granite should be Namurian in age. However, conventional U-Pb dating on zircon (Isotope DilutionThermal Ionization Mass Spectrometry, ID-TIMS) yielded ages indistinguishable within error for the vaugnerite and the granite, around $340 \mathrm{Ma}$ i.e. Middle Visean (Schaltegger et al., 1996: Fig. 3B, a to c). Recent LA-ICP-MS U-Pb zircon age determinations (Tabaud et al., 2015: Fig. 3B, d to f) for other rocks of the Ballons granite complex confirm the general view of an age spectrum spanning from 345 to $336 \mathrm{Ma}$.

\section{Analytical methods}

\subsection{Petrology, mineralogy and whole-rock geochemistry}

Polished thin sections of rocks were observed under optical microscope and mineral chemistry data were acquired using
Scanning Electron Microscopy (SEM) operated by Philippe Recourt at LOG (CNRS - Univ. Lille - ULCO), using a model Quanta 200 from FEI, equipped with an energy dispersive spectroscopy (EDS) Quantax (Bruker) micro-analyser for nondestructive back scattered electron (BSE) imaging and chemical mapping, and with a Centaurus detector with 300$650 \mathrm{~nm}$ photomultiplier for cathodoluminescence (CL) imaging. SEM-EDS chemical maps and analyses were aimed at obtaining a preliminary thermometry from zoned feldspars, at detecting Ti-rich mineral phases required for Ti-in-zircon thermometry-see below details about zircon chemistry acquisition - and at imaging zircon morphology (BSE) and zircon sections (BSE $+\mathrm{CL}$ ) prior to laser ablation. Whole-rock geochemical analyses were performed for each of the dated rocks, on lithium tetraborate-fused pellets. The major elements and $\mathrm{Ba}, \mathrm{Be}, \mathrm{Sc}, \mathrm{Sr}, \mathrm{V}, \mathrm{Y}, \mathrm{Zr}$ were analyzed by Inductively Coupled Plasma-Atomic Emission Spectrometry (ICP-AES), and the other trace elements by ICP-Mass Spectrometry (ICPMS), all listed below with their detection limits.

\subsection{Zircon analyses}

\subsubsection{Zircon extraction}

The rocks were jaw-crushed and sieved under water into granulometric fractions at $50 \mu \mathrm{m}, 100 \mu \mathrm{m}, 160 \mu \mathrm{m}$ and $250 \mu \mathrm{m}$ thresholds. Only the 100-160 $\mu \mathrm{m}$ fraction was further used to avoid disturbed isotopic compositions, for example related to $\mathrm{Pb}$-loss that is enhanced for small zircon grains. In order to spare heavy liquids and considering the abundance of modal biotite - that host the bulk of Fe in those rocks - the $100-160 \mu \mathrm{m}$ fraction was first reduced (of $60 \%$ to $90 \%$ for the vaugnerite samples) using a magnetic Frantz Isodynamic Separator. The heavy grains of the remaining, non-magnetic fraction (at longitudinal angle $25^{\circ}$, lateral angle $7^{\circ}$, maximum intensity $\sim 1.8 \mathrm{~A}$ ) were further separated using heavy liquids (lithium-sodium tetratungstate at $\mathrm{d} \sim 2.84$, and di-iodomethane at $\mathrm{d} \sim 3.23$ ). Zircon crystals were picked under binocular and laid upon a double-faced adhesive tape on a glass plate.

The granite-gneiss yielded limpid, prismatic and pyramidterminated crystals. By contrast, the vaugnerite zircon crystals frequently possess strongly irregular, abnormal shapes (platelets, or very thin needles), unclassical optical characters (e.g. sphene-looking, opaque to dark brown or dark green) and may also look milky to opaque, i.e. highly metamict. Therefore the grains were first observed in BSE, checking their mineral species and imaging the outer morphology of crystals, before being mounted into epoxy and polished so as to expose their equatorial section. The polished grain sections were then imaged, again using SEM-EDS, in BSE and CL to locate fractures, and to detect inherited cores and magmatic zoning.

\subsubsection{Zircon dating and zircon chemistry}

Zircon $\mathrm{U}-\mathrm{Pb}$ isotope measurements and trace element analysis were performed via LA-ICP-MS using a GeoLas-Pro 193 nm ArF Excimer laser system (Lambda Physik) coupled with an Elan DRC-e quadrupole mass spectrometer (Perkin Elmer) at the Institute of Geological Sciences, University of Bern. Ablation was performed with a fluence of $2.5 \mathrm{~J} . \mathrm{cm}^{-2}$, a repetition rate of $9 \mathrm{~Hz}$ and a laser diameter of $32 \mu \mathrm{m}$. A mixture of He $\left(1\right.$ L.mn $\left.{ }^{-1}\right)$ and $\mathrm{H}_{2}\left(0.008 \mathrm{~L} . \mathrm{mn}^{-1}\right)$ was used for 
Table 1. Definition of the QC quality index for the LA-ICP-MS data.

\begin{tabular}{llllllll}
\hline if $|\mathrm{a}-\mathrm{b}| /(\Delta \mathrm{a}+\Delta \mathrm{b})>$ & 2 & 1.4 & 1 & 0.7 & 0.2 & 0.1 & else \\
\hline then $\mathrm{QC}=$ & 0.01 & 0.10 & 0.25 & 0.50 & 0.75 & 0.90 & 1.00 \\
\hline
\end{tabular}

$\mathrm{a} \pm \Delta \mathrm{a}, \mathrm{b} \pm \Delta \mathrm{b}(2 \sigma)$ are the apparent ${ }^{206} \mathrm{~Pb} /{ }^{238} \mathrm{U}$ and ${ }^{207} \mathrm{~Pb} /{ }^{235} \mathrm{U}$ ages \pm errors of a laser spot.

aerosol transport from the ablation cell to the plasma. For U-Pb measurements, the instrument tuning was optimized to increase the sensitivity of heavy masses and to minimize the oxide production, monitored with $\mathrm{ThO}^{+} / \mathrm{Th}^{+}<0.005$. Unknowns were bracketed by zircon standards GJ-1 (Jackson et al., 2004) and NIST SRM-612, which was used for the standardization of element concentration using ${ }^{29} \mathrm{Si}$ as an internal standard. Accuracy and long-term reproducibility were monitored by measuring the zircon standard Plesovice (Sláma et al., 2008). Data reduction was done with the software Iolite 2.5 (Paton et al., 2011) using the Visual age data reduction scheme (Chew et al., 2014) and the error propagation method build into Iolite. For trace element measurements of zircon, the instrument was optimized to ensure a good sensitivity over all masses, maintaining a low oxide production rate. NIST SRM 612 was used as external references standard and ${ }^{29} \mathrm{Si}$ as internal standard. Data reduction was done using SILLS 1.3.2 (Guillong et al., 2008).

\subsubsection{Data reduction}

A 2007 version for Macintosh ${ }^{\mathrm{TM}}$ of the $\mathrm{Excel}^{\mathrm{TM}}$ add-in ISOPLOT3.0 (Ludwig, 2003) was used for plotting U-Pb data and computing age estimates. Moreover, we devised a Quality of Concordance index (QC) quantifying for each $\mathrm{U}-\mathrm{Pb}$ analysis the closeness of its apparent ${ }^{206} \mathrm{~Pb} /{ }^{238} \mathrm{U}$ and ${ }^{207} \mathrm{~Pb} /{ }^{235} \mathrm{U}$ ages to concordance. Denoting those ages as $\mathrm{a} \pm \Delta \mathrm{a}(2 \sigma)$ and $\mathrm{b} \pm \Delta \mathrm{b}$ $(2 \sigma)$, the ratio of the absolute value of a-b to $\Delta \mathrm{a}+\Delta \mathrm{b}$ was computed (Tab. 1). The QC index is best adapted to datasets for which the error ellipses are of comparable sizes. It proved also practical at sorting out vast numbers of LA-ICP-MS data found in the literature, for evaluating their final interpretation, especially for the sample GG4 (loc. Fig. 3A, and see below).

\section{Results}

\subsection{Petrological data and mineral chemistry}

Here we provide a preliminary inventory, illustrating the main differences between the GGC and the vaugnerites, in view of their contrasted geochronological results.

Major mineral constituents common to the granite-gneiss and to the various vaugnerites are quartz, two feldspars, and biotite. First order differences appear in modal compositions (Fig. 4), with seemingly inverse proportions of quartz (30 vol\% versus $5 \%$, resp.) and biotite (3\% versus $25 \%$, resp.). Sillimanite and muscovite (up to $1 \mathrm{vol} \%$ ) are present only in the granite-gneiss, amphibole (up to 20\%) only in the vaugnerites (green sections in Fig. 4D-F). The leucocratic granite-gneiss exhibits a fine-grained grano-lepidoblastic texture with bent biotite flakes, corresponding to a metamorphic foliation (Fig. 4C), while the meso- to melanocratic vaugnerites have an isotropic, much coarser-grained, undeformed granitic texture (Fig. 4A, B, D, E, F, Fig. 5A), with euhedral biotite sections.
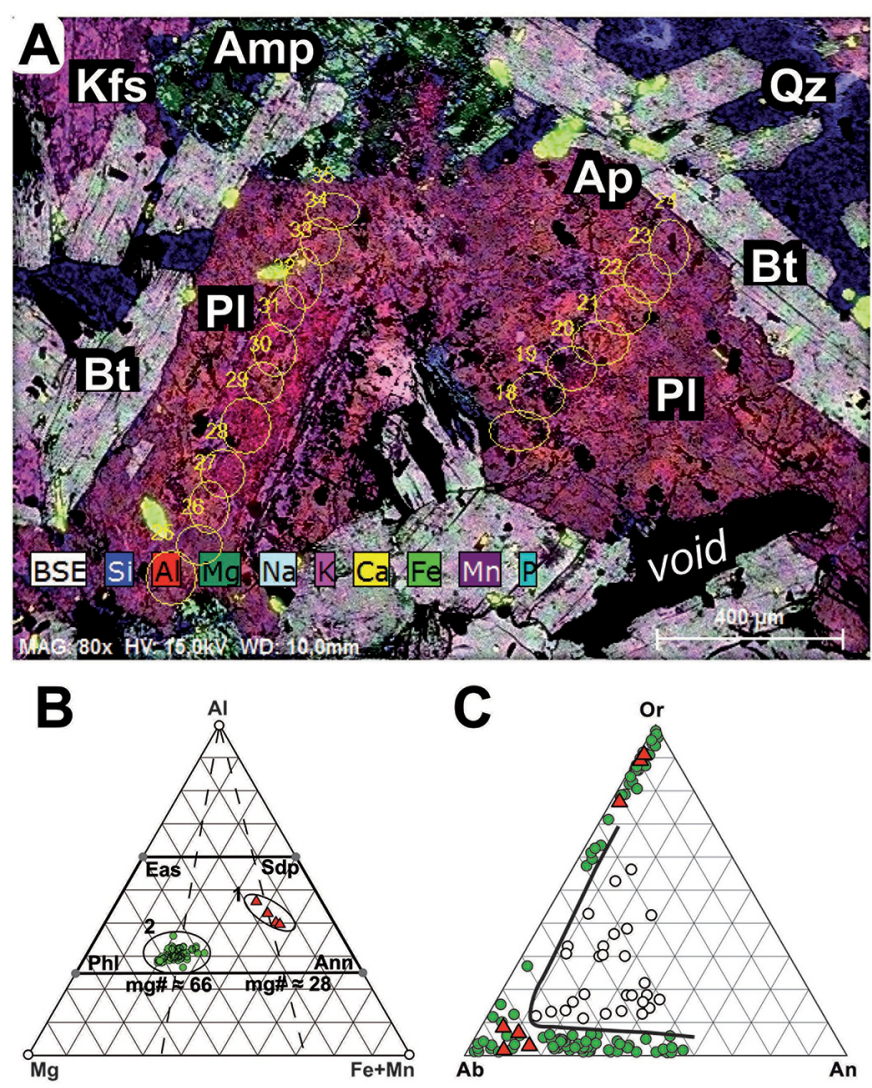

Fig. 5. Mineral chemistry. - A, example of Clefcy vaugnerite microchemical map: mineral abbreviations following Whitney and Evans (2010). Yellow ovals locate feldspar areal-analyses through SEM-EDS. Note the variegated core $(\mathrm{Pl} \pm \mathrm{Kfs} \pm$ sericite) due to subsolidus unmixing, the more uniform rim (oligoclase), and the euhedral biotite $(\mathrm{Bt})$ laths enclosing most of the apatite crystals $(\mathrm{Ap})$. $\mathrm{B}, \mathrm{Al}-\mathrm{Fe}+\mathrm{Mn}-\mathrm{Mg}$ (at.) triangle with biotite SEM-EDS point-analyses for: 1, the Vo14-16, dated granite-gneiss; 2, various vaugnerites. $\mathrm{C}$, triangle Ab-Or-An (mol.), using same symbols as B for point analyses, plus areal-analyses of vaugnerite plagioclase crystals (including the ovals in A) plotted as empty circles to the right of the black line.

SEM-EDS analyses of feldspar and biotite also suggest clear-cut differences between the granite-gneiss and the vaugnerites (Fig. 5). The biotite crystals (Fig. 5B) from all vaugnerites are $\mathrm{Mg}$-rich and Al-poor and plot across the phlogopite-biotite join at $\mathrm{mg} \#$ of $68 \pm 10$. The presumably older, metamorphic biotite of the granite-gneiss plots towards the Fe,Al-rich siderophyllite end-member at $\mathrm{mg} \#$ of $28 \pm 8$. Based on mineral section shapes (euhedral Bt and Amp, subhedral Pl, interstitial Qz), inclusion relationships (e.g. Ap in $\mathrm{Bt}, \mathrm{Bt}$ and Amp in poikilitic Kfs), the crystallization sequence proceeded following the canonical order: (Ap $\pm \mathrm{Thr}), \mathrm{Zrn}$, 
([Cpx?]Amp + Bt), Pl, Kfs, Qz (although a different scenario might be evoked from the image of the Habeaurupt vaugnerite, Fig. 4F, where biotite veins seem to enclose light-colored blasts, hence might have overgrown during a secondary thermal pulse). This order of crystallization was proposed as early as 1968 by Gagny, who also listed the relevant crystallization temperature range for each mineral phase, from $1100-1000^{\circ} \mathrm{C}$ for $\mathrm{Amp}+\mathrm{Bt}$ down to less that $700^{\circ} \mathrm{C}$ for the late $\mathrm{Kfs}+\mathrm{Qz}$. By contrast, the sillimanite-bearing granitegneiss has a granoblastic texture, probably solid-state generated at amphibolite-grade, hence presumably at a much lower temperature $\left(\sim 550-650^{\circ} \mathrm{C}\right)$ than that of the vaugnerite source magmas during their emplacement.

Further indications on the emplacement conditions of the vaugnerites can be sought in their feldspar microchemistry. The pink granite to syenite veins crosscutting Clefcy and Habeaurupt vaugnerites contain red, hematite-rich, subhedral feldspar crystals (Fig. 4D). It is known that Fe in feldspar can growingly substitute to $\mathrm{Al}$ at higher temperatures (Bambauer et al., 1974), before getting exsolved during post-magmatic cooling. Hence, such hematite-rich feldspar might represent a destabilized relict of a syn-intrusive, high- $T$ feldspar. A tentative feldspar thermometry is attempted here upon zoned plagioclase clasts from the Clefcy vaugnerite (Fig. 5A), using the ability to defocus the beam of the SEM-EDS. That allows areal-analyses that may yield a local average approaching the primitive high-T compositions inside zoned plagioclase, presumably grown from ternary high-T feldspars. Indeed, those areal-analyses plot into high-T regions of the feldspar triangle (Fig. 5C). On the same triangle it should be noted that granite-gneiss feldspars (red triangles) are restricted to the alkaline terms, opposed to a much broader range of vaugnerite feldspar compositions (green and empty circles). The black line added to this diagram (Fig. 5C) approximates the $900^{\circ} \mathrm{C}$ isotherm line near a $\mathrm{H}_{2} \mathrm{O}$ pressure at $0.1 \mathrm{GPa}$ (as recently recalled by Kawabata and Shimura, 2019). Hence it can be provisionally proposed that the Clefcy plagioclase (Fig. 5A) began growing as a ternary $\mathrm{Ca}-\mathrm{Na}-\mathrm{K}$ core at $\mathrm{T}>900^{\circ} \mathrm{C}$, now dissociated to $\mathrm{Pl}+\mathrm{Kfs}$, overgrown under decreasing $\mathrm{T}$ by a more albitic rim, itself enclosed by the ultimate freezing of poikilitic/interstitial $\mathrm{Kfs}+\mathrm{Qz}$. Based on more accurate techniques, a similar temperature range was also invoked (Altherr et al., 2019) for a Mg-K, syntectonic, red I-type granite from Schwarzwald.

\subsection{Whole-rock geochemistry}

Geochemical data (Tab. 2) allow (1) the five dated rocks to be classified as ultra-potassic (Fig. 6A); (2) a comparison with the nearby Ballons and Crêtes Mg-K granites (Fig. 6A-B); (3) the assessment of a "vaugnerite identity" among the ultrapotassic clan (Fig. 6C-D), and (4) to comfort the differences between the vaugnerite and the granite-gneiss already observed in the above-listed petrological characters.

Vaugnerite data. With $\mathrm{SiO}_{2}$ from 48 to $58 \mathrm{wt} . \%$, the vaugnerites have Al-saturation index (ASI) in the range 0.70 1.21 , denoting basic to intermediate, metaluminous to slightly peraluminous rocks. High Cr-contents (in the range 270-950 $\mu \mathrm{g}$ / g) and Ni-contents (60 to $250 \mu \mathrm{g} / \mathrm{g}), \mathrm{MgO}$-contents from 5 to 15 wt.\% with $\mathrm{mg} \#$ in the $64-78$ range, suggest a mantle source.
The ratios $\mathrm{Ba} / \mathrm{Rb}$ are smaller than 20 (at 4 to 10 ) and $\mathrm{Rb} / \mathrm{Sr}$ is greater than 0.1 (at 0.4 to 0.9 ), in line with the presence of phologopite, rather than amphibole, at the source (Furman and Graham, 1999). $\mathrm{K}_{2} \mathrm{O}$-contents from 2.7 to $5.3 \mathrm{wt}$.\% evidence ultra- $\mathrm{K}$ rocks that plot in the shoshonite field of the $\mathrm{K}_{2} \mathrm{O}-\mathrm{SiO}_{2}$ diagram (Fig. 6A). In addition, the $\sum$ REEs (in $\mu \mathrm{g} / \mathrm{g}$ ) are in the $107-318 \mu \mathrm{g} / \mathrm{g}$ range and $(\mathrm{La} / \mathrm{Yb})_{\mathrm{N}}$ in the $9-25 \mu \mathrm{g} / \mathrm{g}$ range (Tab. 2). Further characters are listed hereafter because they are also valid for other rocks.

Regional affinities. The Ballons and Crêtes $\mathrm{Mg}-\mathrm{K}$ granites (Tabaud et al., 2015) also plot in the ultra-K field (Fig. 6A) but most samples are intermediate to acid. Two groups are identified based on the REE-normalized profiles (Fig. 6B). The group of the Crêtes granite is characterized by high $(\mathrm{La} / \mathrm{Yb})_{\mathrm{N}}$ from 14 to 30 and $\sum$ REE from 230 to $340 \mu \mathrm{g} / \mathrm{g}$ (Fig. 6B), hence overlapping with the three Central Vosges vaugnerites. Based on the same parameters, with 5 to 19 and 106 to $235 \mu \mathrm{g} / \mathrm{g}$ respectively, the second group comprises the Ballons rocks, to which belongs the Vo15-08 Ballons vaugnerite (Fig. 3B). Along with their high K-content, as shown by spider-diagrams (see Fig. $\mathrm{S} 1) \mathrm{Th}-$, U-, and Pb-enrichments of our vaugnerites and pronounced $\mathrm{Nb}$-, Ti-depletions again match the Ballons and Crêtes $\mathrm{Mg}-\mathrm{K}$ granites.

Vaugnerite name. A geochemical classification of high-K granitoid rocks was proposed by Scarrow et al. (2008) based on an extensive literature coverage. Using their vaugnerite data collection, a spider-diagram - their Fig. 2E-normalized to $\mathrm{N}$ MORB is reproduced here (Fig. 6C). The analyses of the vaugnerites were superimposed. The coincidence is not absolutely perfect but strong $\mathrm{Ti}, \mathrm{Nb}$ depletions and $\mathrm{K}, \mathrm{Pb}$, $\mathrm{Th}, \mathrm{U}$ enrichments of our samples, and the general shape of the spiders, do match the database (note that the same highs and lows appear using a primitive mantle reference, Fig. S1). The authors also performed a factor analysis separating high-K granitoids into three families, namely vaugnerite, shoshonite and K-rich lamprophyre. Their principal factors fn1 and fn2 have been computed (Tab. 2) for each of the four dated vaugnerites. By contrast with the simplistic $\mathrm{K}_{2} \mathrm{O}-\mathrm{SiO}_{2}$ diagram (Fig. 6A), here (Fig. 6D) none of our samples plots into the field of shoshonites. Three of them plot in the vaugnerite field but the Clefcy vaugnerite Vo15-01 deviates by an exceptionally high factor fn 1 , out of any of the established families of ultra-potassic rocks. This is due to its high Th- and high Pcontents (Fig. 6C), linked to the presence of thorite among the heavy minerals (see Fig. 7), and to ubiquitous apatite observed in thin section.

Other individual differences with the reference set of vaugnerites (grey background on Fig. 6C, + in Fig. 6D) of Scarrow et al. (2008) also appear (Fig. 6C) for the Ballons sample (Vo15-08), due to its relatively low $\mathrm{La}, \mathrm{Ce}, \mathrm{Nd}$ contents. No interpretation of this discrepancy is evident although apatite depletion could be invoked. This rock-type belongs to a pluton, compared to the much smaller bodies constituted by the dykes where the other vaugnerites were sampled. Similar pluton/dyke differences have also been noticed by Kubínová et al. (2017) in the Bohemian massif: vaugnerite has "higher amount of mantle-incompatible elements (e.g. Rb, Cs, Ba, Pb, Th, U)" than the "syenite porphyry", considered as parent rock and daughter rock, respectively. 
Table 2. Geochemical data for the dated rocks.

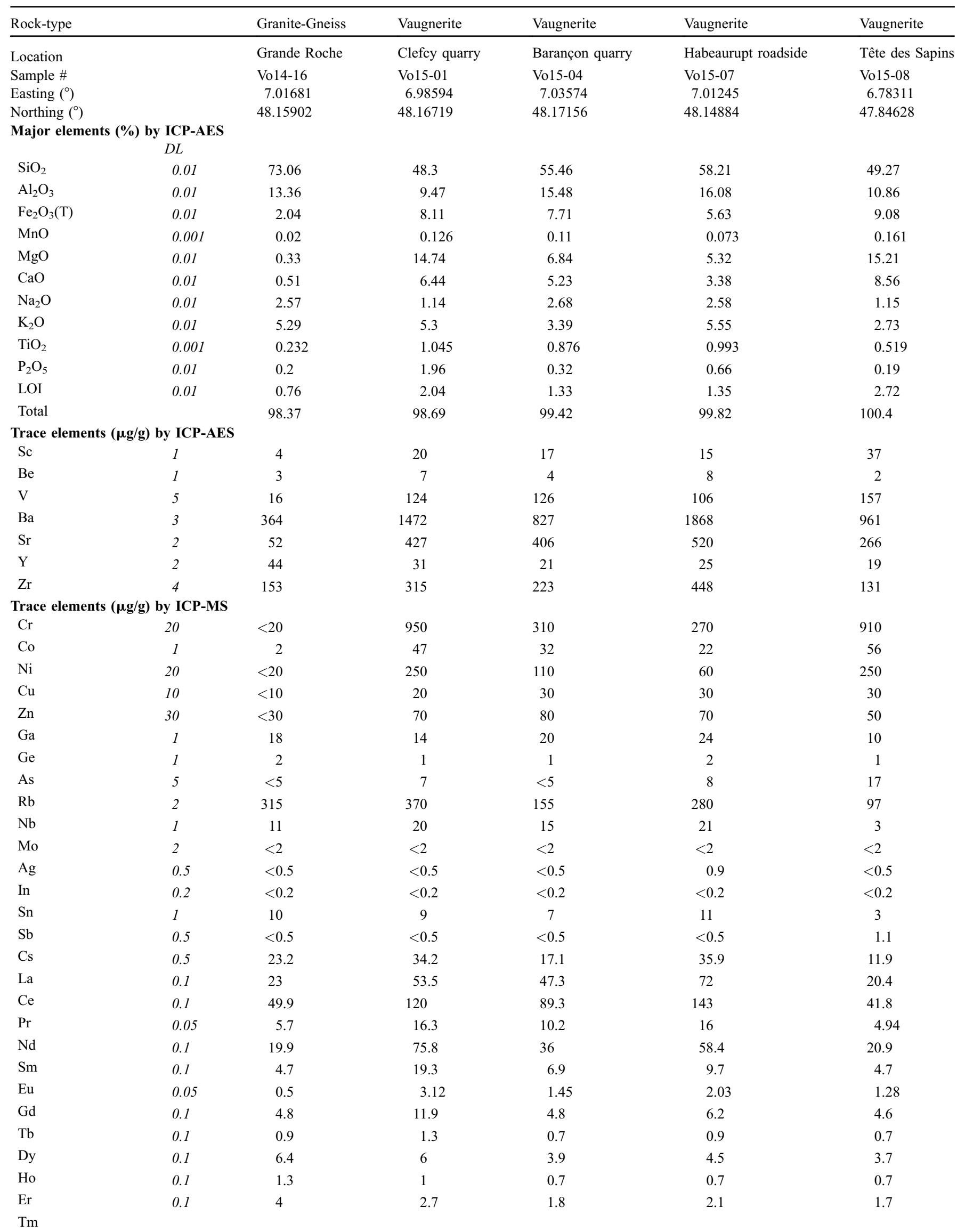


Table2. (continued).

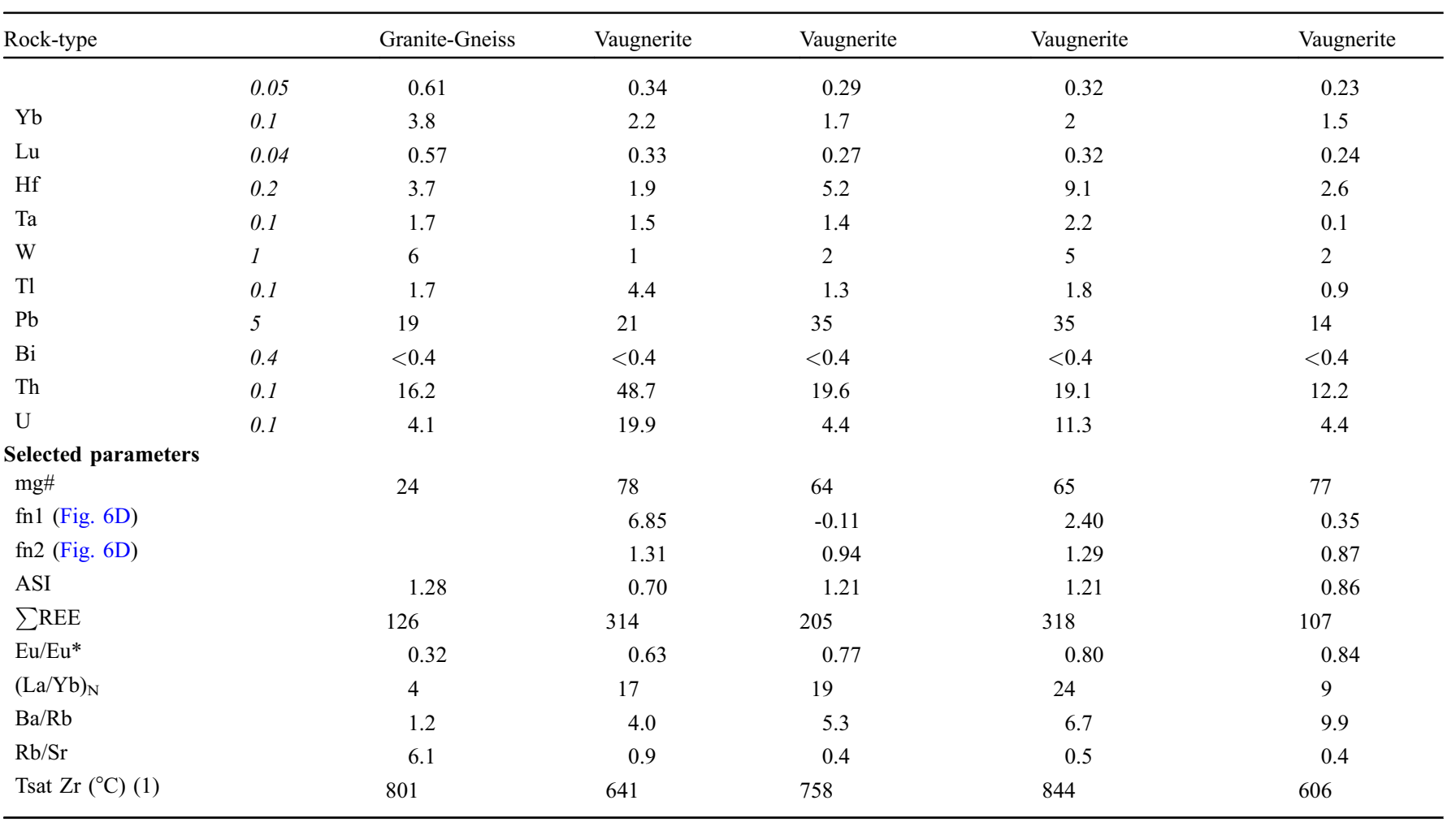

DL: detection limit. LOI: loss on ignition. $\mathrm{mg} \#=100 \mathrm{x} \mathrm{Mg} /\left(\mathrm{Fe}_{\text {total }}+\mathrm{Mg}\right)$ (atomic ratios). fn1 and fn2 are composite factors computed after Scarrow et al. (2008) classification of K-rich granitoids. $\mathrm{ASI}=\mathrm{Al} /(\mathrm{Na}+\mathrm{K}+2 \mathrm{Ca})(\text { at.), aluminium saturation index. (./.) })_{\mathrm{N}}$ denotes a ratio of values normalized to the chondrite reference of Sun and McDonough $(1989)$. Eu/Eu* is the square root of $(\mathrm{Eu} / \mathrm{Gd})_{\mathrm{N}} \mathrm{x}(\mathrm{Eu} / \mathrm{Sm})_{\mathrm{N}}$. (1) TSatZr are zircon saturation temperatures computed after Watson and Harrison (1983).

Granite-gneiss. Alike the $\mathrm{Mg}-\mathrm{K}$ granites and the vaugnerites, the granite-gneiss Vo14-06 plots in the ultrahigh-K field (Fig. 6A). However, compared to the vaugnerites, this rock is more felsic $\left(\mathrm{SiO}_{2}\right.$ at $\left.73.06 \mathrm{wt} . \%\right)$ and has lower Fe-, $\mathrm{Ca}$ - and $\mathrm{Mg}$-contents and low mg\# at 24. The ratio $(\mathrm{La} / \mathrm{Yb})_{\mathrm{N}}$ is also much lower at 4 , corresponding to higher HREEs, and lower LREEs contents than the vaugnerites (Tab. 2 and Fig. $6 \mathrm{~B})$. Interestingly, the Vo14-16 granite-gneiss analysis also presents strong similarities with the GG4 granite-gneiss analysis of Tabaud et al. (2015), for example by its $\mathrm{K}_{2} \mathrm{O}$ and $\mathrm{SiO}_{2}$ contents (Fig. 6A). The same conclusion can be reached based on their REE profiles (Fig. 6B), spider diagrams (Fig. S1) and other geochemical classification diagrams obtained using the GCDkit plotting facility (Janousek et al., 2006). Both samples display a flat HREE pattern, classically attributed to the presence of garnet in the source, together with a marked negative europium anomaly linked to plagioclase crystallization. Their relatively low normalized ratio $(\mathrm{La} / \mathrm{Yb})_{\mathrm{N}}$ evokes transitional felsic magmas and possibly an anorogenic tectonic context because a similar profile is known for A-type granitoids (Guillot et al., 1993). The high $\mathrm{K}_{2} \mathrm{O}$-content of GG4 (5.11 wt.\%, comparable to 5.29 wt.\% for Vo14-06) was instead privileged by Tabaud et al. (2015) for proposing a crustal pattern for the anatectic unit. As a main component of the $\mathrm{Kfs}+\mathrm{Qz}$ leucosome, $\mathrm{K}$ is a probably a highly mobile element in anatectic environment, so this point would deserve further field work, sampling and petrographic investigations. Whatever the nature of the granite-gneiss protolith, potentially obscured by the HTmetamorphism, the marked REE-pattern discrepancy with respect to the vaugnerites precludes at least an hypothesis suggested by the above quoted "anatectic granite" designation of the GGC: the vaugnerites are not derived from partial melts from their host granite-gneiss or, at least, not from this type of granitegneiss.

\subsection{Zircon typology}

SEM imaging of zircon grains as well as the optical characters observed during zircon separation and sorting (Fig. 7; Tab. 3) revealed contrasted patterns. The granite-gneiss Vo14-16 yielded mostly euhedral, convex and limpid zircon grains (Fig. 7A). Their sections observed in cathodoluminescence (CL) show an oscillatory zoning (Fig. 7B). Both features, indeed typical of "classical" zircon grains, point to a magmatic protolith, most probably a granite. By contrast, the Clefcy vaugnerite Vo15-01 zircons display soccer ball shapes, were frequently grown together with thorite and/or apatite (Fig. 7C), and look highly metamict (opaque to dark brown in transmitted light) with a very weak CL suggesting a highly radioactive content (Fig. 7D). Flat-lozenge to arrowheadshaped zircons, deprived of a prismatic part (outgrown by faster growth of the pyramidal faces), were found in the Vo-15-04 vaugnerite (Fig. 7E, F), again with very weak CL. Needle-shaped, often euhedral zircons characterize Vo15-07 

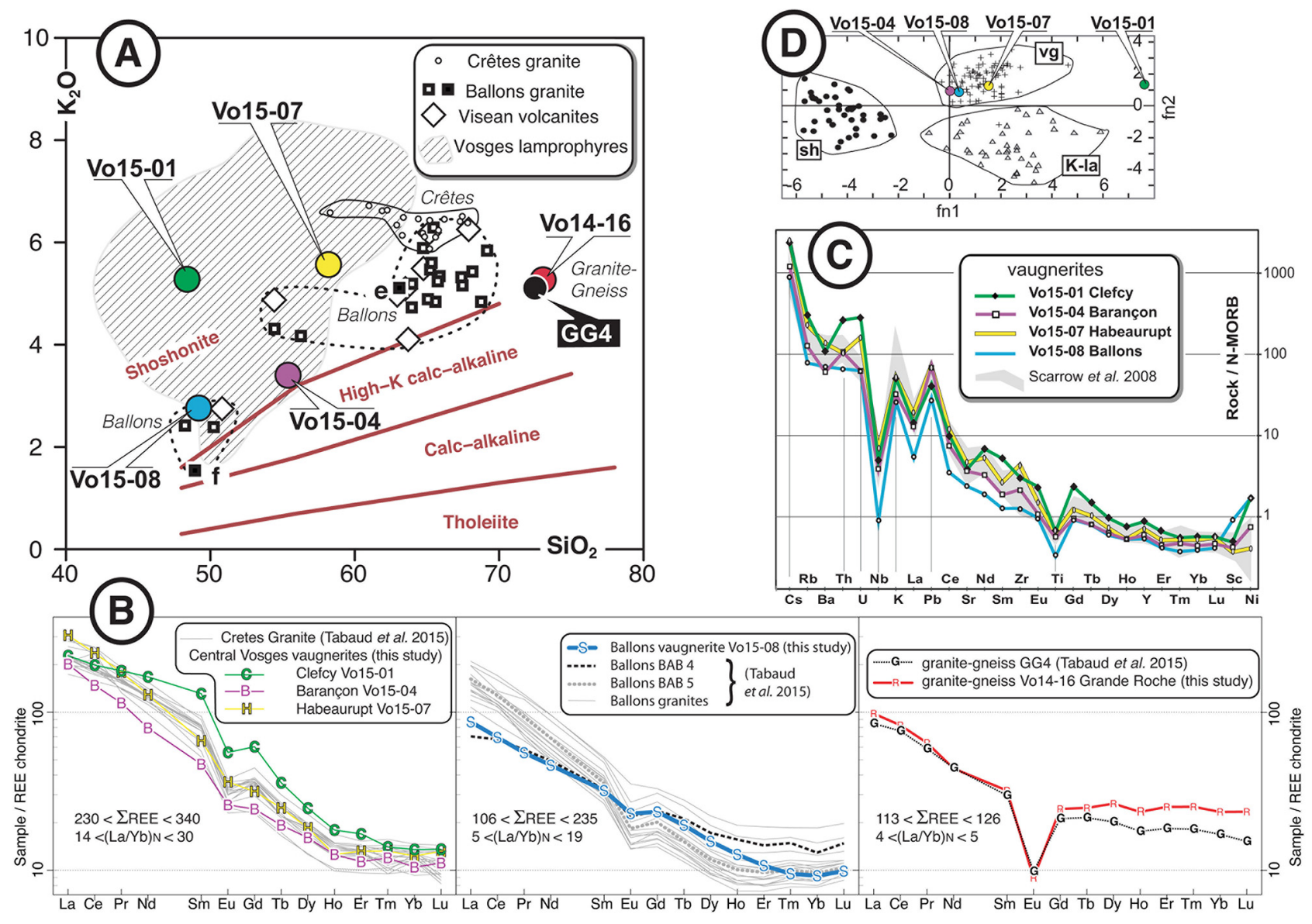

Fig. 6. Geochemistry. - A: $\mathrm{K}_{2} \mathrm{O}$ versus $\mathrm{SiO}_{2}$ plot after Peccerillo and Taylor (1976) for ultra-potassic Vosges rocks. Labelled colour circles: dated rocks of the present study, and granite-gneiss GG4 (loc. Fig. 3A; analysis from Tabaud et al., 2015). Crêtes granite, Ballons granite, Visean volcanites: data from Tabaud et al. (2015) and André (1983). Vosges lamprophyres are 57 analyses from Soder and Romer (2018). Small circles: Crêtes Mg-K granites (18 anal. labelled "CS" and "CN" by Tabaud et al., 2015). Empty squares: Ballons vaugnerites PR1 and 4N from André (1983), and 19 Ballons Mg-K porphyritic granites, labelled "BA" by Tabaud et al. (2015). Black squares: Ballons basic rocks, labelled BAB5 and BAB4 (e and f, resp., as in Fig. 3B). Empty diamonds: Ballons Visean volcanic rocks ( 8 anal. "VO” from Tabaud et al., 2015). - B: REE profiles for the dated rocks of the present study (reference chondrite values from Anders and Grevesse, 1989) grouped with profiles of selected samples (see A for details) from Tabaud et al. (2015), with mention for each group of the sum of the rare earth element contents (in $\mu \mathrm{g} / \mathrm{g}$ ) and the normalized ratio $(\mathrm{La} / \mathrm{Yb})_{\mathrm{N}}-$ C: spidergram of the dated vaugnerites, reference N-MORB values from Hofmann (1988) following J. Scarrow (pers. comm. to FG). Grey: vaugnerite compilation by Scarrow et al. (2008, their Fig. 2E). — D: Labelled colour circles: dated vaugnerites of the present study, plottted using factors fn1 and fn2 of Scarrow et al. (2008, their Tab. 3 and Fig. 8) with their compiled data of: sh, shoshonites $(\bullet)-\mathrm{K}$-la, K-lamprophyres $(\Delta)-$ vg, vaugnerites $(+)$.

and Vo15-08 vaugnerites (Fig. 7G-J), with a stronger CL signature revealing a slightly oscillatory zoning with rarer sector zoning and a frequent axial, tubular cavity that is commonly observed in zircons of subvolcanic, rapidly emplaced magmatic rocks (Pupin, 1980). Those last characters evoke a fast growth, far from equilibrium conditions, related below to a probable fast undercooling of the vaugnerite magma. Whatever their interpretation is, the poorly zoned CLsections have to be related to the fact that, during the LA-ICPMS runs, no clear cut age or chemistry differences were found between various locations in the same zircon crystal (Fig. 7F).

\subsection{Zircon chemistry and thermometry}

\subsubsection{Zircon Th and $U$}

From average $\mathrm{Th}$ and $\mathrm{U}$ contents obtained during the zircon microchemical analyses (Tabs. S4-S5), Th/U ratios were compared to the host rock ratios (Tab. 4). They confirm the highly radioactive character of zircons from Clefcy (Vo15-01) and Barançon (Vo15-04) vaugnerites with the sum of Th- and Ucontent averages at 6753 and $3750 \mu \mathrm{g} / \mathrm{g}$, respectively. This has to be kept in mind for the interpretation of the $\mathrm{U}-\mathrm{Pb}$ isotopic data, since such high U- and Th-contents in zircon favour its metamictization and enhance radiogenic $\mathrm{Pb}$-loss, hence disturbing the $\mathrm{U}-\mathrm{Pb}$ isotopic ratios and hampering precise age determinations. The average $\mathrm{Th} / \mathrm{U}_{\mathrm{Zrn}}$ ratios, from 0.27 to 0.72 (Tab. 4), exceed 0.1 and hence point to zircons originated from magmatic rocks (Rubatto, 2002), alike the above listed petrological features. Zircon-rock distribution coefficients $\left(\mathrm{D}_{\mathrm{Zrn} / \mathrm{rock}}\right.$ in Tab. 4) were used to compute the associated equilibrium temperature (Wang et al., 2011; Kirkland et al., 2015). The latter ( $\mathrm{T}_{\mathrm{eq}}$ in Tab. 4), higher than the zircon saturation temperatures (Tab. 2) suggest that zircons grew under disequilibrium conditions (Kirkland et al., 2015). Overcooling conditions leading to supersaturation may be 

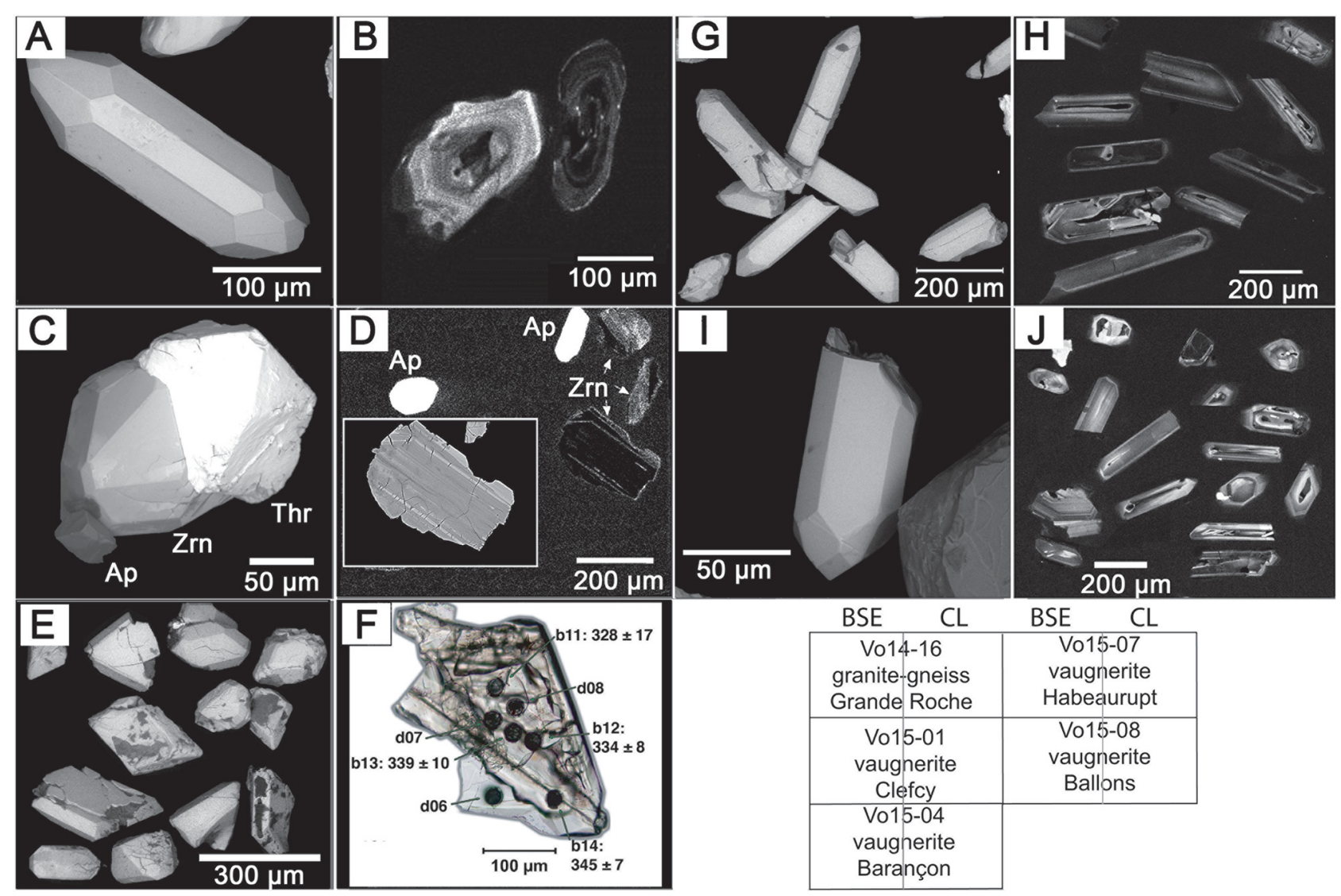

Fig. 7. Zircon grain morphology observed under SEM-BSE (A, C, E, G, I) and zircon section observed under SEM-BSE (insert in D), SEM-CL (B, D, H, I), and optically (F, transmitted light). In C and D, Ap, Zrn, Thr are apatite, zircon, thorite grains, resp. Dark circles in F are LA-ICP-MS craters; d06 to d08: trace-element analyses; b11 to b14: U-Pb isotopic analyses, with the related age (in Ma, $\pm 2 \sigma$ ).

Table 3. Zircon external and internal morphology. Indexing after Caruba and Turco (1971) for prismatic (100 and 110) and pyramidal faces (211 and 101).

\begin{tabular}{|c|c|c|c|c|}
\hline Sample & $\begin{array}{l}\text { Extracted } \\
\text { zircon }(\mu \mathrm{g} / \mathrm{g})\end{array}$ & $\begin{array}{l}\text { Whole-rock } \\
\text { Zr content } \\
(\mu \mathrm{g} / \mathrm{g})\end{array}$ & Zircon grains & Zircon sections \\
\hline Vo15-01 & $<607$ & 315 & $\begin{array}{l}\text { Short, multi-facetted soccerballs, } \\
\text { cracked by internal inflation; highly } \\
\text { metamict, creamy pattern under direct } \\
\text { light (binocular); almost opaque, dark } \\
\text { brown in transmitted light }\end{array}$ & $\begin{array}{l}\mathrm{KF} \text {, biot, thorite, apatite inclusions, very } \\
\text { dark in } \mathrm{CL}\end{array}$ \\
\hline Vo15-04 & 230 & 223 & $\begin{array}{l}\text { Pale pink and milky but transparent; } \\
\text { often irregularly, step-facetted, or as } \\
\text { easily broken arrowheads; looking } \\
\text { corroded and/or fast crystallized }\end{array}$ & Dark in CL \\
\hline Vo15-07 & 261 & 448 & $\begin{array}{l}\text { Mostly elongate needles, clear, euhedral, } \\
100>110 \text { up to } 100 \text { alone, } 101>211 \text { up } \\
\text { to } 101 \text { alone }\end{array}$ & $\begin{array}{l}\text { Dark in CL, biotite inclusions, axial } \\
\text { (glassy?) inclusions in elongate sections }\end{array}$ \\
\hline
\end{tabular}


Table 4. Averages of zircon Th- and U-contents $(\mu \mathrm{g} / \mathrm{g})$ and of $\mathrm{Th} / \mathrm{U}$ ratios.

\begin{tabular}{|c|c|c|c|c|c|c|c|c|c|c|}
\hline Sample & $n$ & $\mathrm{Th}_{\mathrm{Zrn}}$ & \pm & $\mathrm{U}_{\mathrm{Zrn}}$ & \pm & $\mathrm{Th} / \mathrm{U}_{\mathrm{Zrn}}$ & \pm & $\mathrm{Th} / \mathrm{U}_{\text {rock }}$ & $\mathrm{D}_{\mathrm{Zrn} / \mathrm{rock}}$ & $\mathrm{T}_{\mathrm{eq}}\left({ }^{\circ} \mathrm{C}\right)$ \\
\hline Vo15-01 & 15 & 2306 & 1636 & 4447 & 2392 & 0.47 & 0.16 & 2.45 & 0.21 & 881 \\
\hline Vo15-07 & 12 & 305 & 278 & 847 & 519 & 0.33 & 0.08 & 1.69 & 0.21 & 880 \\
\hline Vo15-08 & 30 & 476 & 243 & 692 & 366 & 0.72 & 0.21 & 2.77 & 0.25 & 850 \\
\hline
\end{tabular}

linked to fast cooling, with two transitional saturation thresholds inducing transitions from bulky to hopper, and from hopper to dendritic crystal morphologies (Sunagawa, 1981). That may account for the above-imaged arrowhead or acicular zircon crystal shapes (Fig. 7).

\subsubsection{Zircon REE profiles}

Ninety zircon chemical analyses are listed as supplementary data (Tab. S4). This dataset was filtered and reduced based on the anomalous or normal pattern of the REE profiles. At first glance (Fig. 8A-E), the profiles are somewhat erratic for the Clefcy vaugnerite zircons (Fig. 8B) and for the Barançon vaugnerite (Fig. 8D), a little less disordered for the granitegneiss zircons (Fig. 8C) that have the highest HREE contents, and still better grouped for the Habeaurupt (Fig. 8E) and Ballons (Fig. 8F) vaugnerites, the latter showing the most coherent data. Anomalous REE-profiles were sorted out using a chemical alteration index from the literature (Bell et al., 2019). According to their chaotic pattern, none of the Clefcy zircon profiles passed this test (Fig. 8B) and only 3 among 12 Barançon (Fig. 8D) profiles succeeded, 4 among 12 for the Habeaurupt vaugnerite (Fig. 8E) with the best score ( 7 among 15, Fig. 8F) for the Ballons vaugnerite.

Comparing the zircon profiles with reference data from the literature (Fig. 8G-H) shows a distinct HREE enrichment of the granite-gneiss zircons coupled with LREE sometimes below detection limits (Fig. 8I), a pattern mainly observed in zircons from anorogenic contexts. By contrast, the vaugnerite zircon profiles present relatively low HREE, a typical feature of zircons from continental arc granitoid or continental postcollisional granitoid (Belousova et al., 2002; Rubatto, 2002), with the lowest values for the Ballons sample (Fig. 8L) that has the most coherent, best grouped data.

\subsubsection{Zircon thermometry}

Two methods were applied. The first is based on the zircon Ti-content, that increases with $\mathrm{T}$ and at fixed $\mathrm{T}$ with the activity of $\mathrm{TiO}_{2}$ in the magma (Watson et al., 2006). The Ti-content was determined during the LA-ICP-MS runs (Tab. S4). The second (Watson and Harrison, 1983), using whole-rock contents (Tab. 2) of $\mathrm{Zr}, \mathrm{Si}, \mathrm{Al}, \mathrm{Ca}, \mathrm{Na}, \mathrm{K}$, is an estimate of the zircon saturation temperature, the T-threshold under which zircon starts crystallizing.

Ti-in-zircon. With this thermometry in view, a SEM session was devoted at detecting Ti-rich minerals in our thin sections. No titanite was found. Rutile in vaugnerites was found exclusively as exsolutions, less than $20 \mu \mathrm{m}$ in size, in biotite and to a lesser extent in amphibole. The rutile grains were apparently grown during late- to post-magmatic destabilization of their hosts. During the magmatic stage, Ti was mainly fixed as a constituent of biotite (where we measured up to $3 \mathrm{wt} . \% \mathrm{TiO}_{2}$ ) and the $\mathrm{TiO}_{2}$-activity was probably low. By contrast, dendritic $\mathrm{TiO}_{2}$ was observed in the granite-gneiss as mm-sized sections in the $\mathrm{Qz}+\mathrm{Kfs}+\mathrm{Bt}$ background, and also as exsolutions inside biotite sections. Thus, Ti-in-zircon temperatures (Fig. 9) were computed for two values of $a_{\mathrm{TiO} 2}$, namely 1 , possibly valid for the granitegneiss pre-metamorphic protolith, and 0.1 , preferred value for vaugnerites. The zircon of the granite-gneiss have crystallized at a minimal temperature of $755^{\circ} \mathrm{C}$, and those of vaugnerites from $875^{\circ} \mathrm{C}$ to $1076^{\circ} \mathrm{C}$ depending on the activity of $\mathrm{TiO}_{2}$ (Fig. 9). The thermometry results in the granite should be considered at best as minimal estimates after Schiller and Finger (2019), and might underestimate the zircon crystallization temperature by as much as $70^{\circ} \mathrm{C}$. Considering also the dispersion of the experimental points, a minimum $\pm 70^{\circ} \mathrm{C}$ error is proposed for each result.

Zircon saturation. Obtained following Watson and Harrison (1983) the results are listed along with the geochemical data (Tab. 2) from which they are directly computed. The granitegneiss zircon saturation temperature, at $801{ }^{\circ} \mathrm{C}$, is within uncertainty in line with the Ti-in-zircon figure. For the vaugnerites the concordance between the two methods is far from good, with definitely lower zircon saturation temperatures (Tab. 2), but the conditions recommended for this parameter, namely "crustal anatectic melts" (Watson and Harrison, 1983) are probably not fulfilled by the vaugnerites.

As a whole, estimating temperature for zircon crystallization is certainly not a straightforward task for vaugnerites (Fig. 9). According to Kirkland et al. (2015), our results show that the vaugnerite zircons have endured a disequilibrium crystallization at temperatures definitely lower than the equilibrium temperature $\mathrm{T}_{\mathrm{eq}}$ (theoretical, corresponding to crystallization from a melt) from the same authors. The temperature pattern of zircon from the plutonic vaugnerite Vo15-08 (Ballons) suggest a relatively quiet, stable plutonic environment when compared to the erratic results obtained for some vaugnerite dykes (Vo15-01, Vo15-07), presumably much more forcefully and turbulently emplaced.

\section{5 $\mathrm{U}-\mathrm{Pb}$ dating of zircon}

Age determinations rely on selected graphical representations (Fig. 10). Supplementary data comprise the rough data (Tab. S5) together with normal (Fig. S2) and inverse (Fig. S3) Concordia plots. Apparent ages are ${ }^{206} \mathrm{~Pb} /{ }^{238} \mathrm{U}$ and errors are given at 2 sigma-level. 

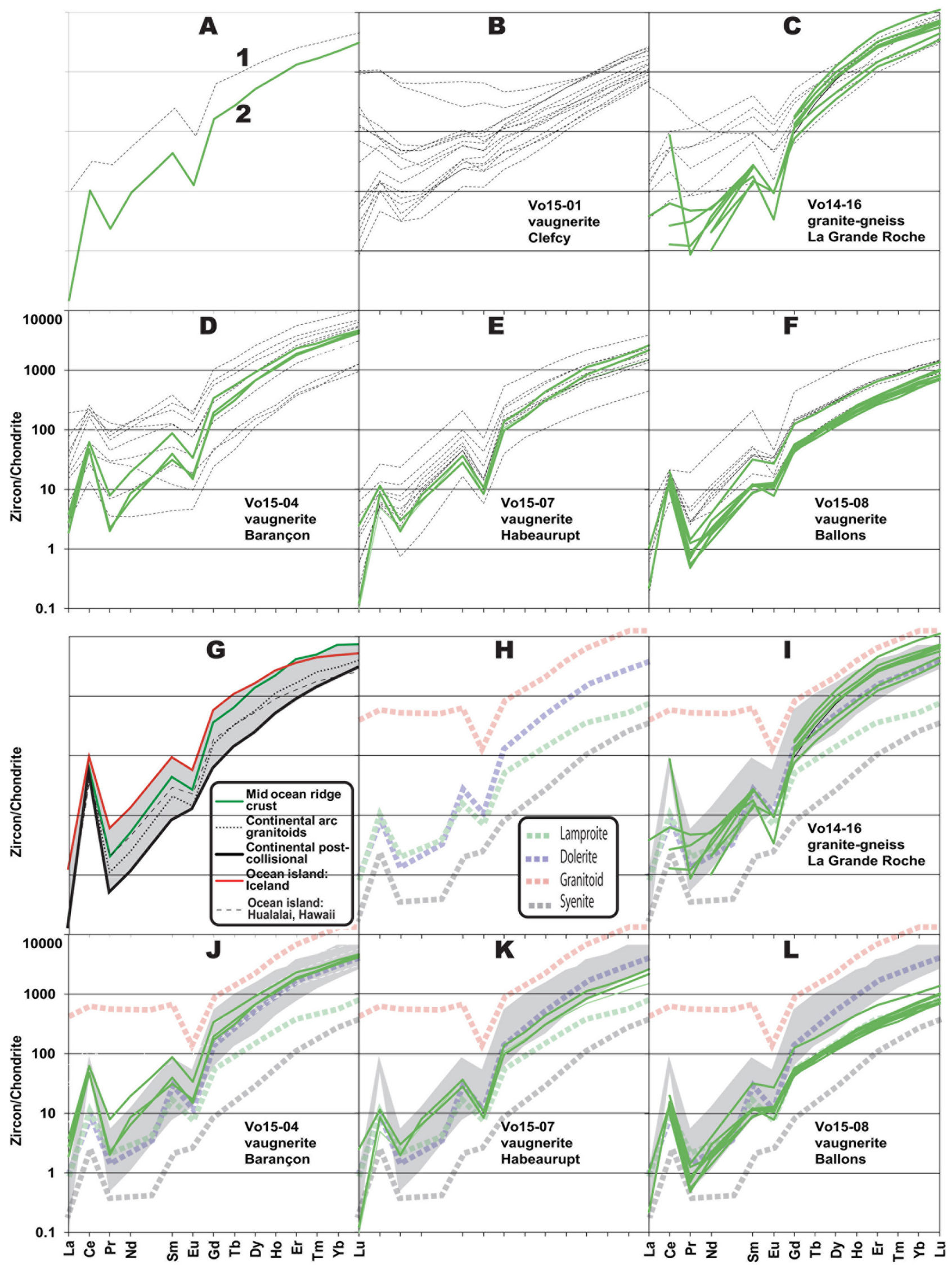


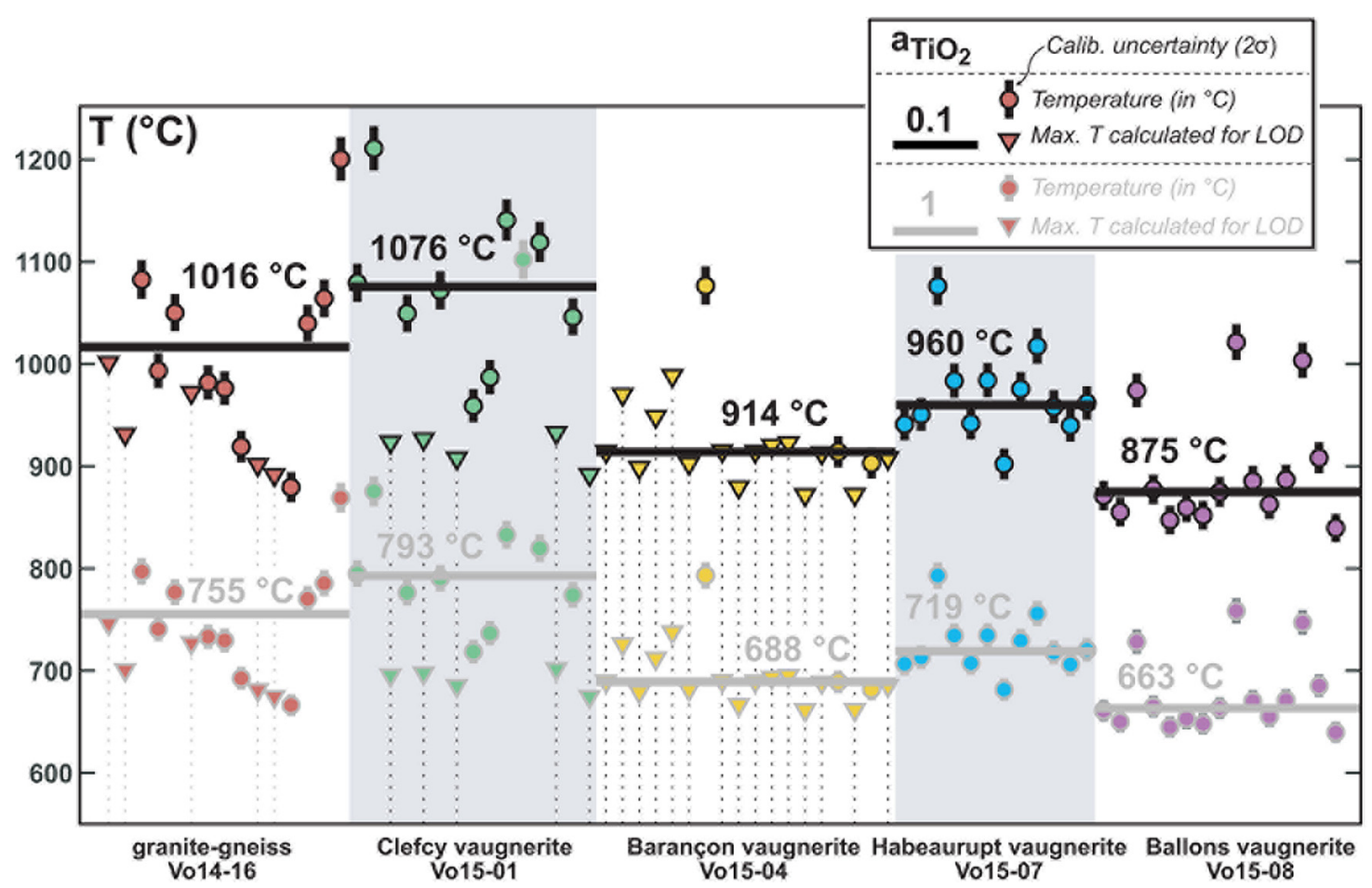

Fig. 9. Ti-in-zircon temperatures obtained using the calibration of Watson et al. (2006) for $a_{\mathrm{TiO} 2}=1$ (gray lines) and $a_{\mathrm{TiO} 2}=0.1$ (black lines). Triangle markers indicate maximal temperatures calculated using the limit of detection (LOD) value obtained with the method of Pettke et al. (2012). Calibration uncertainty from Watson et al. (2006) is given at the $2 \sigma$ level. The best Ti-in-zircon temperature estimate of each sample was taken as the median of all analyses above LOD, following Schiller and Finger (2019).

\subsubsection{Vo14-16, granite-gneis (Central Vosges): sillimanite- bearing leucocratic gneiss}

After 80 runs on unknown zircon grains and standards, among 44 spots on 29 zircon sections, 32 sub-concordant to concordant dates were retained (graph A1 in Fig. 10), all with $\mathrm{QC} \geq 0.5$. The distribution of the ${ }^{206} \mathrm{~Pb} /{ }^{238} \mathrm{U}$ apparent dates, removing three outliers (at $334 \pm 7,545 \pm 21,558 \pm 18 \mathrm{Ma}$ ), shows 29 dates in the range 424 to $489 \mathrm{Ma}$, with a WBEM at $451 \pm 7 \mathrm{Ma}$ (A2 in Fig. 10). Keeping only the twelve data that score at $\mathrm{QC} \geq 0.90$, the WBEM yields $455 \pm 12 \mathrm{Ma}$ (excluding two outliers at 334 and $545 \mathrm{Ma}$ ). Repeated on the ten remaining data, computing the WBEM yields $451 \pm 9 \mathrm{Ma}$, excluding the oldest result at $486 \mathrm{Ma}$. As a whole, a conservative estimate of the age of the protolith of the leucocratic gneiss is thus $451 \pm 9 \mathrm{Ma}$. Older concordant ages at $545 \pm 21$ and $558 \pm 18 \mathrm{Ma}$ might represent inherited Precambrian xenocrysts, while the only younger age at $334 \pm 7$ Ma matches the emplacement age of the vaugnerites. This age suggests a metamorphic imprint linked to the vaugnerite emplacement.

To our knowledge, only one attempt was made for dating a sample of granite-gneiss. Tabaud et al. (2015) found a subconcordant cluster and a lower intercept age of $321.6 \pm 2.8 \mathrm{Ma}$, that they retained for a sample GG4 called "western Central Vosges Granite", a choice comforted by concordant data from monazite extracted from another granite. Nevertheless, among their 38 spots on zircon for this GG4 sample of granite-gneiss (see above, Fig. 3A, Fig. 6A, B), the best QC's (=1) are for ${ }^{206} \mathrm{~Pb} /{ }^{238} \mathrm{U}$ ages at $346,429,459$ and $466 \mathrm{Ma}$ and the whole data set averages at $384 \pm 100 \mathrm{Ma}(2 \sigma)$. The above-mentioned clustered dates from 318 to $333 \mathrm{Ma}$ have QC's of 0.01 or 0.25 for 5 among 9 data. Oppositely, 15 of their data are grouped between 420 and $460 \mathrm{Ma}$, i.e. equal within error to our age estimate. Such pattern points to the particularly heterogeneous, probably polyphase character of the granite-gneiss unit.

\subsubsection{Vo15-08, Ballons peri-plutonic vaugnerite (Southern Vosges)}

From a total of 45 runs, among 23 operated on 18 zircon sections, 21 yielded sub-concordant or better results. The ${ }^{206} \mathrm{~Pb} /{ }^{238} \mathrm{U}$ dates scatter from $338 \pm 5$ to $370 \pm 6 \mathrm{Ma}$ (B1 in Fig. 10), with sixteen spots having a $\mathrm{QC}$ at 0.75 , three spots at 0.9 and two spots at 1 (B2 in Fig. 10), at $338 \pm 5 \mathrm{Ma}$ and $339 \pm 6 \mathrm{Ma}$. The WBEM of the ${ }^{206} \mathrm{~Pb} /{ }^{238} \mathrm{U}$ dates for these 5 best data yields an estimate of $343 \pm 10 \mathrm{Ma}$, with, however,

Fig. 8. Zircon REE-profiles. A to F: all analyses. The data have been filtered using the Light Rare Earth Element Index LREEI $=(\mathrm{Dy} / \mathrm{Nd})+(\mathrm{Dy} /$ Sm) alike Bell et al. (2019). A, caption for B to F with: 1: LREEI < 40, altered zircon. 2: LREEI > 40, valid zircon chemistry. Only valid data (C to F) have been further used, excluding Clefcy zircon data (B). G: reference profiles according to plate tectonics context (Grimes et al., 2015, to which missing $\operatorname{Pr}$ values were added stating $(\mathrm{Nd} / \mathrm{Pr})_{\mathrm{N}}=2.2$, based on the average of our valid zircon profiles). H: reference profiles according to host rock-types (Belousova et al., 2002). I to L, valid zircon profiles from our dated rocks, with grey background showing the range of the reference profiles $\mathrm{G}$, and dotted lines for $\mathrm{H}$ profiles, respectively. 
Vo14-16, granite-gneiss La Grande Roche
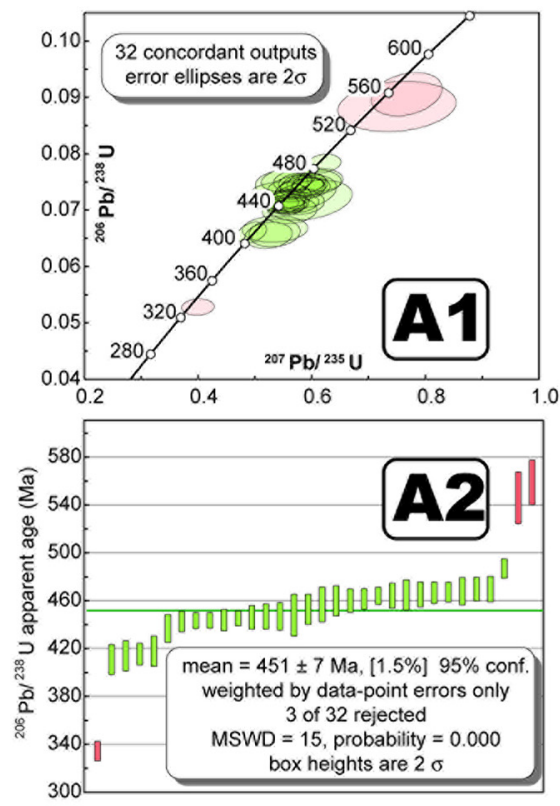

Vo15-07, vaugnerite dyke Habeaurupt
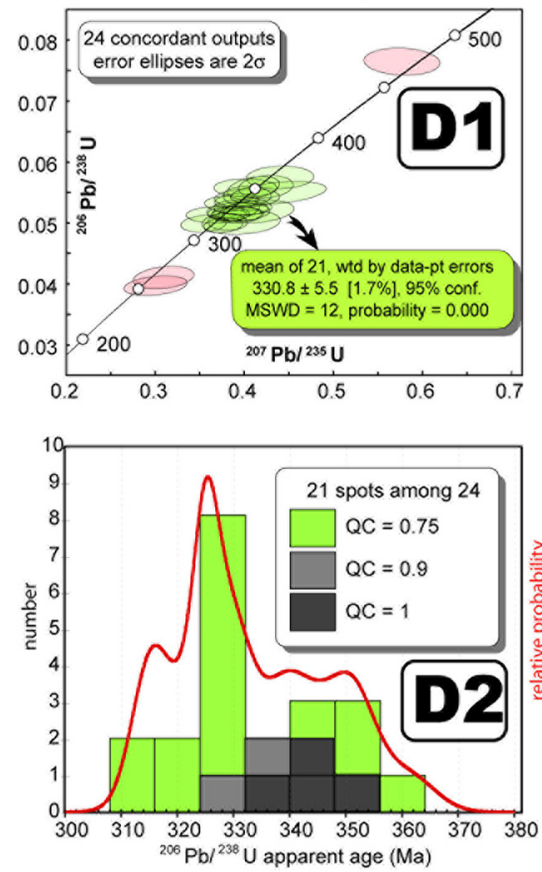

Vo15-08, plutonic vaugnerite Tête des Sapins
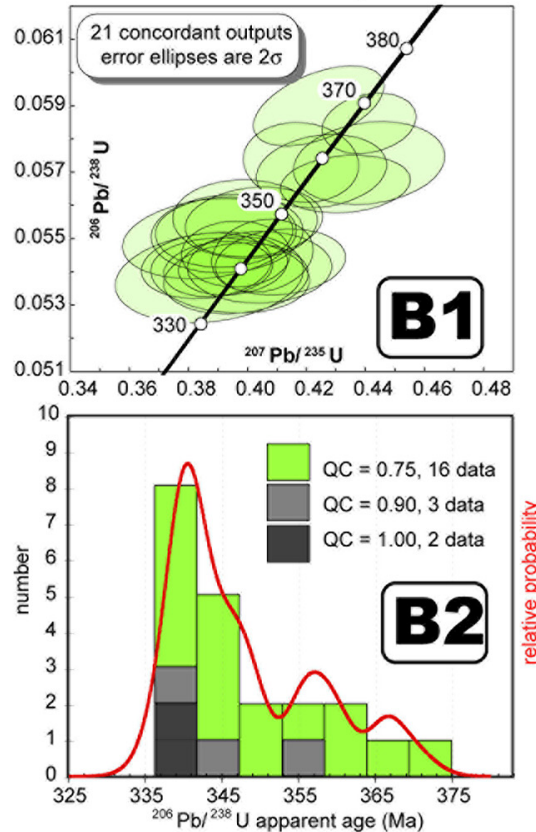

\section{Vo15-01, vaugnerite dyke} Clefcy quarry


Vo15-04, vaugnerite dyke Barançon quarry
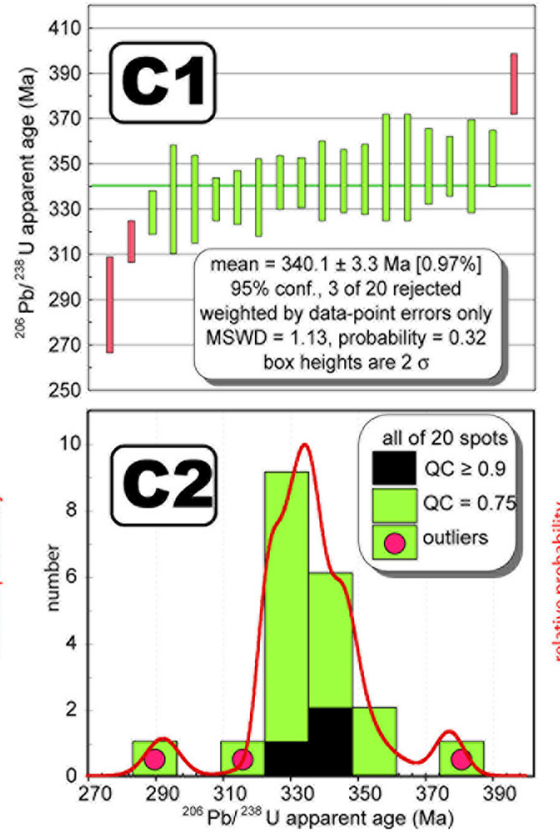

\section{Preferred age estimates $( \pm 2 \sigma)$}

A $\quad 451 \pm 9 \mathrm{Ma}$

B $\quad 340 \pm 2.5 \mathrm{Ma}$

C $\quad 340 \pm 7 \mathrm{Ma}$

D $336 \pm 10 \mathrm{Ma}$

E $\quad 340 \pm 25 \mathrm{Ma}$

Fig. 10. Geochronology U-Pb. Concordia diagrams (A1, B1, D1, E1), probability density plot of ${ }^{206} \mathrm{~Pb} /{ }^{238} \mathrm{U}$ ages $(\mathrm{B} 2$, C2, D2), weighted average plot of ${ }^{206} \mathrm{~Pb} /{ }^{238} \mathrm{U}$ ages (A2, C1, E2).

one spot at $359 \pm 6 \mathrm{Ma}$ apart from a group of four that stay within error into the $[333,348]$ interval (B2 in Fig. 10). Hence, computing the WBEM on these four spots, an age of $340 \pm 2.5 \mathrm{Ma}$ can be proposed as the best estimate for the magmatic age of this plutonic vaugnerite.
This matches closely the ID-TIMS results of Schaltegger et al. (1996), with $342 \pm 1$ and $339.5 \pm 2.5 \mathrm{Ma}$ found for the Ballons granite and for a "monzodiorite satellite intrusion", respectively. Their monzodiorite corresponds closely to our vaugnerite, following the minute descriptions of André (1983). 
Indeed, this good match is also suggestive of the pertinence, in this easy case, of the above-defined QC index.

\subsubsection{Vo15-04, Barançon quarry vaugnerite dyke (Central Vosges)}

After fifty runs, 17 zircon grains were tried that yielded 20 sub-concordant data. Their WBEM ${ }^{206} \mathrm{~Pb} /{ }^{238} \mathrm{U}$ age at $340.1 \pm 3.3 \mathrm{Ma}$ ( $\mathrm{C} 1$ in Fig. 10), based on seventeen data ( 3 outliers at 377, 292, and $322 \mathrm{Ma}$ ) matches, within error, the location of the three best QC: $335 \pm 7.4$ at $1 ; 337.6 \pm 7.3$ at 0.9 ; $355 \pm 19$ at 1 (C2 in Fig. 10). The rather large uncertainties of those data are taken into account by proposing a generously conservative estimate at $340 \pm 7 \mathrm{Ma}$ as the emplacement age of the Barançon vaugnerite.

\subsubsection{Vo15-07, Habeaurupt vaugnerite dyke (Central Vosges)}

Twenty-four concordant dates were obtained after 48 laser runs, among which three outliers at 254, 262 and $474 \mathrm{Ma}$ are clearly separated from a main group in the 314 to 362 range (D1 in Fig. 10). The distribution of the 21 remaining data yields a main mode ( 8 data) at $330 \mathrm{Ma}$, beside the group of best concordant data (QC $\geq 0.9 ; n=6)$ that centers around $342 \pm 10 \mathrm{Ma}$ (D2 in Fig. 10). Taking into account such a discrepancy, the Habeaurupt vaugnerite dyke emplacement can be (very) conservatively estimated at $336 \pm 10 \mathrm{Ma}$.

\subsubsection{Vo15-01, Clefcy quarry vaugnerite dyke (Central Vosges)}

Standards and unknown zircons were subjected to 59 laser runs, where 22 spots on 17 zircon sections yielded only 11 subconcordant to concordant results, broadly scattered within error from 310 to $376 \mathrm{Ma}$ (E1 in Fig. 10).

Among the 11 sub-concordant remaining data, the best QC-index of 1 corresponds to a ${ }^{206} \mathrm{~Pb} /{ }^{238} \mathrm{U}$ age at $359 \pm 6 \mathrm{Ma}$, two at 0.9 are for $366 \pm 10$ and $353 \pm 5 \mathrm{Ma}$, the eight remaining data $(\mathrm{QC}=0.75)$ ranging from $316 \pm 5(2$ data) to $354 \pm 6$. A central, numerically dominant group of five data clusters near $340 \mathrm{Ma}$. Hence, with such a tri-modal distribution of concordant results (E2 in Fig. 10; WBEM at $338 \pm 9$ Ma but with MSWD of 31), it is difficult to assess a crystallization age for the Clefcy vaugnerite more precise than $340 \pm 25 \mathrm{Ma}$.

Here is obviously a difficult case, where the QC-index does not yield a straightforward interpretation. It is worth noting that the Clefcy vaugnerite zircons were suspected not to be optimal candidates for dating based on their corroded and opaque pattern observed during the separation (Tab. 3), their abnormal geochemistry (Fig. 8) and their close association with thorite (Fig. 7C). Their peculiar richness in $\mathrm{U}$ and Th (Tab. 4), also observed on Vo15-01 whole-rock geochemistry (Tab. 2), is suggested to have enhanced radiogenic $\mathrm{Pb}$-loss. The dispersion of apparent ages would be thus the result of such anomalous characters rather than faithfully reflecting superimposed crystallization ages.

\section{Discussion and integration into the Vosges Variscan geodynamical framework}

The zircon ages obtained by laser ablation ICP-MS for the 3 vaugnerite dyke samples of Central Vosges and 1 periplutonic vaugnerite intrusive at the northern border of the Ballons granitic complex in the Southern Vosges provide consistent ages of $340 \pm 7 \mathrm{Ma}$ for zircon crystallization in the Barançon dyke, $336 \pm 10 \mathrm{Ma}$ for the Habeaurupt dyke, $340 \pm 2.5 \mathrm{Ma}$ for the peri-plutonic Ballons intrusive and $340 \pm 25 \mathrm{Ma}$ for the Clefcy dyke. Despite some partial alteration of the radiochronometric signal, in particular for the Clefcy vaugnerite (see above), the measured age pattern can be interpreted as related to the emplacement of the vaugnerite intrusives in a relatively short time span of $5 \mathrm{Ma}$ i.e. from ca 340 to $335 \mathrm{Ma}$.

The leucocratic sillimanite-bearing granite-gneiss at $\mathrm{La}$ Grande Roche in Central Vosges yields a weighted average zircon age of $451 \pm 9 \mathrm{Ma}$ that indicates a pre-Variscan protolith of Upper Ordovician age. This granite-gneiss belongs to the highly heterogeneous Central Vosges Granite-Gneiss Complex (Fig. 2; see also Sect. 2.3, above) that can be considered as a large migmatite complex incorporating relicts of the granulitefacies gneiss units, i.e. the Monotonous and Varied gneiss units of Skrzypek et al. (2014) and "western Central Vosges Granite" dated at $321.6 \pm 2.8$ in the Gérardmer area by Tabaud et al. (2015). Slightly older ages were found for the anatectic event in the eastern part of the Central Vosges i.e. $329 \mathrm{Ma} \pm$ $2 \mathrm{Ma}$ and $326 \pm 5 \mathrm{Ma}$ (Schulmann et al., 2002) suggesting a relatively long-lasting crustal melting event, subsequent to the emplacement of the vaugnerite intrusives.

Our data thus argue for the vaugnerite intrusions to appear as a relatively early magmatic phase within the Late Variscan orogenic period (i.e. Middle Visean in age). They thus corroborate the results of Tabaud et al. (2015), considering the vaugnerite intrusives as the mafic expressions of the more felsic ultra-potassic magmatic suites of the Central and Southern Vosges dated at $337 \mathrm{Ma}$ for the syn-kinematic "granite des Crêtes" and between 345 and $336 \mathrm{Ma}$ for the "granite des Ballons" complex. Volcanic venues evolving towards high-K to shoshonitic affinities on top of the Visean turbidite sequence of the Southern Vosges volcano-sedimentary basin (Lefèvre et al., 1994; Lakhrissi, 1996) and dated by conventional U-Pb methods at $340 \mathrm{Ma} \pm 2$ and $336+3 /-5$ (Schaltegger et al., 1996), are also likely surface products of this pervasive ultra-potassic magmatic event.

At a larger scale, this ca 340-335 Ma-old Central-Southern Vosges ultra-potassic magmatism can be associated to widespread coeval high-K events along the Variscan suture zones (von Raumer et al., 2013) i.e. from the Moldanubian units of the Bohemian massif to the East (between 338 and $335 \mathrm{Ma}$ after Janousek and Holub, 2007; 338.6 Ma \pm 0.7 and $337.9 \mathrm{Ma} \pm 0.2$ after Kubínová et al., 2017) to the northern border of the French Massif Central to the West (i.e. Monts du Lyonnais at $335.7 \mathrm{Ma} \pm 2.1$, Laurent et al., 2017) through the external Alps (i.e. Belledonne massif between 343 and $335 \mathrm{Ma}$, Debon et al., 1998; Aar massif at $334 \mathrm{Ma} \pm 2.5 \mathrm{Ma}$, Schaltegger and Corfu, 1992). In the Moldanubian units of the Bohemian massif, moreover, this pervasive ultra-potassic 
magmatism occurs in close connection with HT-HP felsic granulites, another expression of a major thermal imprint upon the previously thickened crust (Janousek and Holub, 2007). The geodynamic origin remains debated, for this coherent magmatic event at the orogen scale, but it implies a major change in the dynamics of the lithospheric-scale subductioncollision system.

The vaugnerites studied here display heterogeneous petrological characters as well as hybrid geochemical signatures. Recently published petrogenetic models of Variscan vaugnerite-durbachite-lamprophyre type rocks and their association with more felsic high-K plutons in the Bohemian massif (Holub, 1997; Gerdes et al., 2000; Parat et al., 2010; Krmicek et al., 2016; Kubínová et al., 2017), the Vosges massif (Tabaud et al., 2015) and the French Massif central (Couzinié et al., 2016; Laurent et al., 2017; Martin et al., 2017) invariably support some partial melting of a primary metasomatized mantle source (i.e. phlogopite- and/or amphibole-bearing peridotite; see also Condamine and Médard, 2014; Förster et al., 2019 and Gao et al., 2019 for a more general perspective) and contamination at lower crustal depths by variable amount of crustal sources (Gerdes et al., 2000; Couzinié et al., 2016). This implies high heat flux at the base of the lithosphere, classically interpreted as resulting from significant thermal erosion of the lithospheric mantle in relation with sub-continental asthenosphere upwelling (e.g., Henk et al., 2000). These conditions can be achieved either within the mantle wedge above an active subduction i.e. a supra- subduction setting (e.g., Menant et al., 2018) or in post-orogenic settings, associated to the different types of removal of the lithospheric roots of subduction-collision systems (slab break-off, convective removal of the thermal boundary layer, lithospheric delamination; e.g. Henk et al., 2000 and references herein). The post-orogenic setting was generally considered in the Bohemian and Vosges massifs, relating the ultra-potassic magmatism and the coeval felsic granulites emplacement to the break-off and/or sinking of previously (i.e. Late Devonian) subducted slabs (i.e. a Saxothuringian slab for Janousek and Holub, 2007; a Rheic slab for von Raumer et al., 2013; a Moldanubian slab for Kubínová et al., 2017) as well as underplating of associated continental crust (i.e. the Saxothuringian crust after Skrzypek et al., 2014 and Tabaud et al., 2015). The latter model, referred to as relamination, differs from others in that the heat necessary for melting both the lithospheric mantle and the crust is produced in situ by radiogenic heating associated to the long-term burial (around 10-15 Ma) of the subducted Saxothuringian continental crust at the base of the Moldanubian crust (Lexa et al., 2011).

Whatever the precise proposed mechanism is, such postorogenic models strongly minimize the role of the active Rhenohercynian subduction which, considering the geological context of the Vosges massif, implies a total decoupling between the Northern and Central-Southern Vosges along the Lalaye-Lubine fault zone. Moreover, they also disconnected the ca $340 \mathrm{Ma}$ ultra-potassic magmatism from the major geodynamical change recorded in the Vosges at the same time: the transition from a pervasive extensional (or transtensional) stage expressed by the strong subsidence of the Southern Vosges volcano-sedimentary basin to the compressional orogenic wedge stage from Middle Visean times onward (e.g., Schulmann et al., 2002).

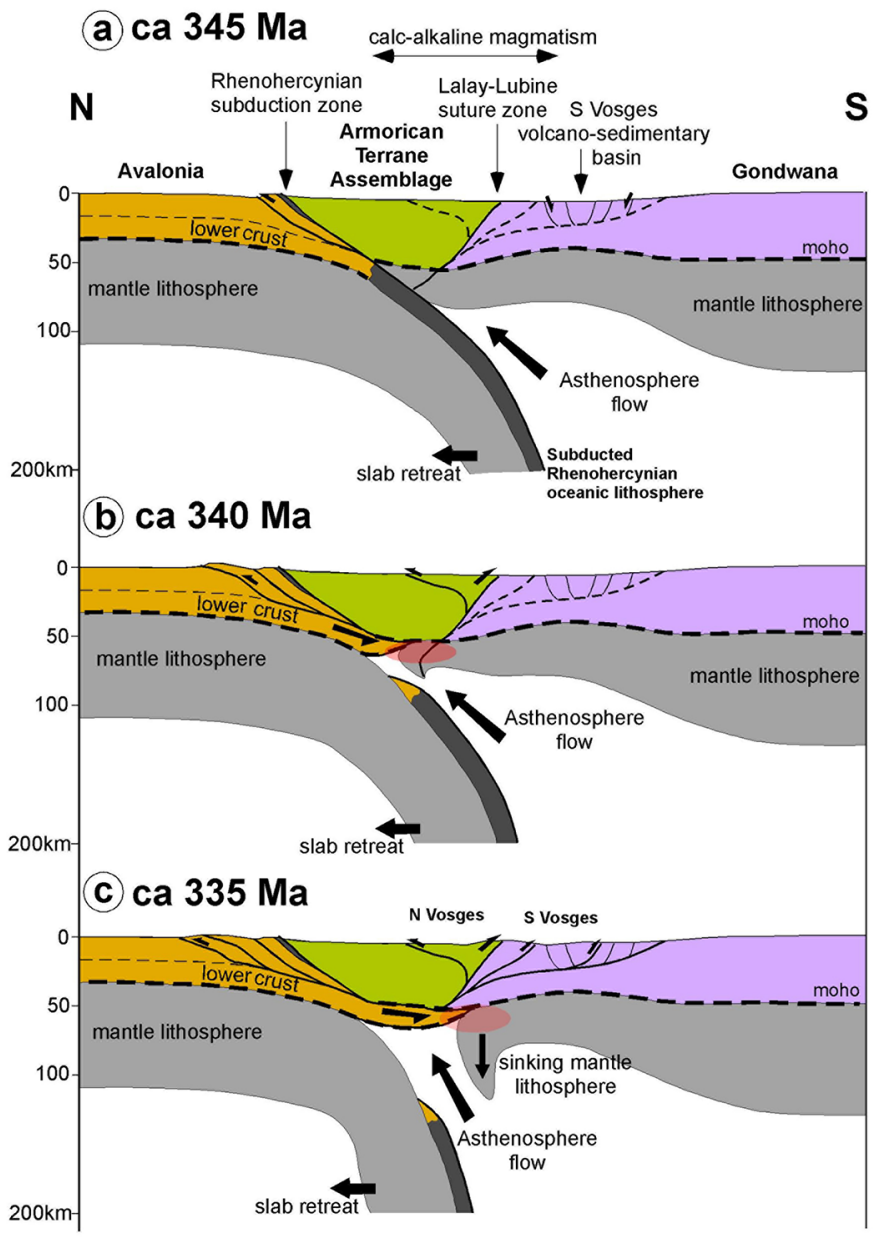

Fig. 11. Sketch geodynamical model of the syn-collisional lithosphere delamination process proposed as the main driving mechanism for the development of the major ultra-potassic magmatic pulse in the Central-Southern Vosges at ca $340-335$ Ma. a. ca 345 Ma stage: transition from oceanic to continental subduction along the Rhenohercynian trench; note the development of arc-type calcalkaline magmatism forming the western extension of the MidGerman Crystalline Rise and back-arc extension localizing the Southern Vosges volcano-sedimentary basin. b. ca 340 Ma stage: onset of the colliding process and mantle lithosphere delamination; note the underthrusting of the Avalonian lower crust in between the Saxothuringian crust and mantle. The red zone refers to the possible zone of melting of the metasomatized mantle forming the initial source of the vaugnerites. c. ca 335 Ma stage: Southward (i.e. retro) propagation of thrusting within the Central-Southern Vosges massif and of the subcrustal delamination front with progressive sinking of the decoupled mantle lithosphere. Note the resultant parallel migration of the asthenospheric upwelling and of the associated melting zone of the metasomatized mantle (red zone).

We propose here an alternative model integrating the whole geological data into a consistent geodynamical framework connected to the dynamics of the Rhenohercynian subduction-collision system. Syn-collisional delamination of the supra-subduction mantle lithosphere is proposed (Fig. 11), following the general model of mature collision proposed by Gray and Pysklywec (2012) based on thermo-mechanical 
models. As emphasized by Eisele et al. (2000), the development of the Late Devonian-Lower Carboniferous Southern Vosges sedimentary basin together with widespread coeval calc-alkaline volcanic activity can be regarded as the arc-back-arc extensional system of the retreating Rhenohercynian subduction slab. They can also be considered as the markers of a long-lasting thermal erosion of the mantle lithosphere below the previously thickened SaxothuringianMoldanubian orogenic complex, very likely associated to protracted asthenospheric flow inside the Rhenohercynian subduction wedge (Fig. 11a). Considering such a situation by Latest Devonian times, the orogenic roots of the Eovariscan Saxothuringian-Moldanubian wedge are necessary to have been removed by slab break-off much earlier, possibly during the early (ca 380-370 Ma) exhumation of HP-UHP rocks as proposed by Matte (1998) based on the continental subduction models of Chemenda et al. (1996).

As shown by thermo-mechanical simulations (Morency and Doin, 2004), protracted asthenospheric flow within the supra-subduction mantle wedge and the associated thermal erosion of the mantle lithosphere can promote the favorable thermal conditions at the base of the crust for the decoupling of the lithospheric mantle from the overlying crust (i.e. Moho temperatures above around $800^{\circ} \mathrm{C}$ following Morency and Doin, 2004), thereby enhancing the initiation of mantle delamination (Fig. 11b). The latter is expected subsequently to propagate away from the trench, i.e. the later suture zone, by propagation at the base of the crust of a localized shear zone and progressive sinking of the mantle lithosphere due to its negative buoyancy with respect to the underlying asthenosphere (Fig. 11c) (Schott and Schmelling, 1998; Houseman and Molnar, 2001; Morency and Doin, 2004; Gray and Pysklywec, 2012).

Another piece of evidence for the decoupling of the crust and the mantle lithosphere in the supra-subduction Saxothuringian-Moldanubian plate can be found in the lack of around $200 \mathrm{~km}$ of thinned Avalonian lower crust within the Rhenohercynian thrust wedge as emphasized by large-scale balanced cross sections (Oncken et al., 2000). This critical point implies that the Avalonian lower crust was detached from its upper crust (accreted inside the Rhenohercynian wedge) and subsequently involved in the subduction channel to some lithospheric mantle depth, in a transient state, then very likely underplated at the base of the Saxothuringian-Moldanubian crustal assemblage (Oncken, 1997; Franke and Stein, 2000; Krawczyk et al., 2000). As noted in a recurrent way for the European Variscan belt (e.g. Ménard and Molnar, 1988), this configuration is strongly comparable to that of the HimalayaTibet orogenic belt where a sheet of Indian lower crust is considered to be largely underthrust below the Asian crust, possibly by around $300 \mathrm{~km}$ to the north of the suture zone (e.g., DeCelles et al., 2002). A lower crustal underthrust requires the mechanical decoupling of crust and mantle lithosphere for both the subducted plate (i.e. the Avalonian plate) and the suprasubduction plate (i.e. the Saxothuringian-Moldanubian assemblage)(Fig. 11b-c) forming a double delamination type of wedges following the classification of Moore and Wiltschko (2004). An alternative scenario involves the underplating of the Avalonian lower crust enhanced by the break-off of the underlying slab as proposed recently by Magni et al. (2017). In absence of any argument supporting slab break-off in our case, a retreating Rhenohercynian mantle slab is sufficient to account for some total decoupling with the comparatively buoyant underplated Avalonian continental lower crust. The detachment at depth of the subducted Avalonian lower crust from its lithospheric mantle and its propagation between the Saxothuringian-Moldanubian crust and mantle necessarily implies some transfer of shortening into adjacent crustal units thereby marking the onset of collision.

On the other hand, fluids expelled from the long-lasting Rhenohercynian subducted crust are likely to have participated to metasomatizing the overlying lithospheric mantle (Martin et al., 2017). Some asthenospheric retro-propagating corner flow at the zone of contact in between the advancing underplated Avalonian continental lower crust and the delaminated upper-plate lithospheric mantle would enhance partial melting of both the metasomatized lithospheric mantle and surrounding continental crustal blocks (Avalonia, Armorican Terrane Assemblage, Gondwana; see reddish zone in Fig. $11 \mathrm{~b}-\mathrm{c}$ ) thereby producing the hybrid magmas at the origin of the observed ultra-potassic magmatism. The contribution of these different continental units to the parental magmas is possible to partly account for to the various crustal sources involved in the Central and Southern Vosges magmatic suites (respectively, deeply subducted mature and juvenile crustal material) as suggested by $\mathrm{Sr}-\mathrm{Nd}$ isotopic data (Tabaud et al., 2015). The migration of these hybrid magmas into the upperplate is likely to be controlled by active thrust faults (probably partly inherited from the Eovariscan shortening) and more generally, by "uplift channels of exhumed HP rocks" as proposed in the Bohemian massif by Finger et al. (2009) which could explain the preferential localization of the vaugnerites and related high-K associations within the exhumed granulites of the Central Vosges.

In the proposed model, the extensive ca 340-335 Ma ultrapotassic magmatic event observed in the Central-Southern Vosges represents the onset of the syn-collisional delamination of the mantle lithosphere above the Rhenohercynian subduction. As proposed by Gray and Pysklywec (2012), the propagation of the delamination front away from the suture zone and the related subcrustal asthenospheric upwelling (Fig. 11c) is expected to induce a parallel delay in the emplacement of ultra-potassic magmatic associations. Such southward migration is not possible to be investigated directly on a transverse passing through the Vosges. The N-S evolution of zircon ages of vaugnerites from the eastern Massif Central (from ca $337 \mathrm{Ma}$ in the Monts du Lyonnais area to ca $300 \mathrm{Ma}$ in the Velay dome) supports, however, the existence of such a long-lasting delamination-induced magmatic event, inducing coeval crust and mantle melting, and propagating southward from the suture zone towards the southern Variscan thrust front (Laurent et al., 2017). Such a southward migration was also noted by Finger et al. (2009) for the Saxo-Danubian Granite Belt, interpreted as a whole as a result of some Late Variscan mantle lithosphere delamination.

In the Vosges massif, such persistent thermal anomaly, due to the syn-collisional mantle lithosphere delamination from $340 \mathrm{Ma}$ on, can have triggered the protracted pervasive migmatization recorded in the Central Vosges granite-gneiss unit at least from 329 to $322 \mathrm{Ma}$ (Tabaud et al., 2015). On the other hand, the progressive retreat of the Rhenohercynian mantle slab and the related propagation of the asthenosphere 
wedge (Fig. 11c) would possibly explain the general younger ages of both the high-K associations and the subsequent anatectic granites in the Northern Vosges units (respectively at ca $312 \mathrm{Ma} \pm 2 \mathrm{Ma}$ and ca $300 \mathrm{Ma}$ following Tabaud et al., 2014). A main point to emphasize on a tectonic point of view is that most of these magmatic intrusives emplaced within a predominant collisional setting propagating outward towards the Northern and Southern Variscan thrust front up to the Late Westphalian times (Upper Pennsylvanian, at ca $305 \mathrm{Ma}$ ) (e.g., Oncken, 1997; Matte, 2001; Averbuch et al., 2004). The subcrustal delamination is suggested, however, to localize bands of syn-convergent extension within the internal parts of the orogen as shown by the thermo-mechanical modelling simulations of Gray and Pysklywec (2012) accounting for the synorogenic extension frequently characterized in the Variscan internal massifs (Burg et al., 1994; Faure, 1995; Faure et al., 2009). The extensive extensional collapse of the Variscan belt was effective only by Stephanian-Lower Permian times $(305-280 \mathrm{Ma})$ as recorded by the widespread highly subsiding rift-related intermontane troughs of the Variscan internal massifs (i.e. the Lorraine-Sarre-Nahe and St Dié-Villé basins considering the Vosges massif region) (Averbuch and Piromallo, 2012) thereby giving rise to a basin-and-range like Late Variscan morphology (Ménard and Molnar, 1988). Driving mechanisms for such a transition are still unclear (see for example the discussion in Henk, 1997) but regarding the syn-collisional delamination model proposed here, the final slab break-off of the Rhenohercynian mantle slab (and possibly that of the delaminated Saxothuringian-Moldanubian-Gondwanian lithospheric mantle) are considered as plausible mechanisms to enhance the onset of a stage of post-orogenic tectonic collapse. By the Late CarboniferousEarly Permian times, delamination resulted in a large scale heat anomaly and rejuvenation of the mantle lithosphere below the Variscan internal zones that can be considered as the main trigger for the subsequent long-term thermal subsidence of the NW European Upper Permian-Mesozoic successor basins such as the Paris basin (Prijac et al., 2000; Averbuch and Piromallo, 2012).

\section{Conclusion}

The data presented in this study for four Vosges vaugnerite yield additional constraints on the time-space distribution of the well-developed, ultra-potassic, mantle-derived, magmatic suites, typical of the late collisional evolution of the Variscan suture zones. Here the vaugnerites appear either as a basic rim of the Ballons granite pluton in Southern Vosges, or as isolated dykes cutting across the GGC, a large heterogeneous migmatite unit of the Central Vosges. In "La Grande Roche" quarry, the GGC is shown here to comprise a sillimanitebearing, leucocratic gneiss, that yielded LA-ICP-MS U-Pb zircon age of $451 \pm 9 \mathrm{Ma}$. This "granite-gneiss" derives from a pre-Variscan Upper Ordovician protolith

The four vaugnerite intrusives display specific magmatic characters expressed by assemblages composed of $20-40 \% \mathrm{vol}$ of $\mathrm{Mg}$-rich biotite [ \pm amphibole] at $64<\mathrm{mg} \#<78$, as well as by mafic to intermediate, metaluminous to slightly peraluminous geochemical signatures. Geochemical data preclude the possibility for the vaugnerites to result from the partial melting of the surrounding GGC.

Zircon grains extracted from the different vaugnerite samples recorded $\mathrm{U}-\mathrm{Pb}$ ages of $340 \pm 2.5 \mathrm{Ma}$ (Southern Vosges), $340 \pm 25 \mathrm{Ma}, 340 \pm 7 \mathrm{Ma}$ and $336 \pm 10 \mathrm{Ma}$ (Central Vosges). Within uncertainty, the Southern Vosges pluton-like type and the Central Vosges dyke-like type vaugnerites thus display the same age around 340-335 Ma i.e. mid-Visean, that can be interpreted as the age of emplacement of the vaugnerite intrusives into the host gneissic sequence. This age interval corresponds to that of the major Central-Southern Vosges granite complexes (ca. $337 \mathrm{Ma}$ for the syn-kinematic "granite des Crêtes" and in between 345 and 336 Ma for the "granite des Ballons" complex; Tabaud et al., 2015) as well as that of the major high-K volcanic rocks within the Late Devonian-Visean Southern Vosges turbidite basin (340 Ma \pm 2 and $336+3 /-5$; Schaltegger et al., 1996).

As previously stated by Tabaud et al. (2015) in the Vosges and as also recognized on a broader scale from the northern Massif Central to the Bohemian massif (e.g., Janousek and Holub, 2007; von Raumer et al., 2013; Kubínová et al., 2017; Laurent et al., 2017), the vaugnerite intrusions form part of an extensive mid-Visean ultra-potassic magmatic event indicative of a significant partial melting of the metasomatized mantle below these Variscan internal domains. The onset of this magmatic pulse at ca. $340 \mathrm{Ma}$ corresponds in the Vosges to a major geodynamical change (e.g., Schulmann et al., 2002) with the transition from an extensional (or transtensional) setting controlling the development of the S Vosges Late Devonian-Lower Visean turbidite volcano-sedimentary basin (very likely in a back-arc position with regards to the underlying Rhenohercynian subduction; Eisele et al., 2000; Tabaud et al., 2014) towards a compressional setting inducing the southward propagation of thrusting and deformation into the turbidite basin (Petrini and Burg, 1998; Skrzypek et al., 2012a). The ultra-potassic magmatic event thus signs in the Vosges the transition from supra-subduction to collision.

Based on the results of thermo-mechanical simulations of mature collisional systems (Gray and Pysklywec, 2012), we propose that this pervasive mantle melting event was associated to the syn-collisional lithospheric delamination of the Saxothuringian-Moldanubian supra-subduction continental block above the Rhenohercynian slab. Delamination of the lithospheric mantle is suggested to occur as the result of increasing temperature at the Moho through a protracted asthenospheric flow into the Rhenohercynian subduction wedge. The progressive southward (retro-verging) decoupling and sinking of some mantle lithosphere slab resulted in the parallel propagation of both the deformation front and the latecollisional ultra-potassic magmatism as suggested by the progressive younger ages of the Late Variscan vaugnerites towards the southern parts of the Eastern Massif Central i.e. from ca. $335 \mathrm{Ma}$ in the Monts du Lyonnais to ca. $300 \mathrm{Ma}$ in the Velay area (Laurent et al., 2017). Such course of events, initiated in a collisional context at ca. $340 \mathrm{Ma}$ along the suture zones, finally resulted in the extensional collapse of the Variscan belt, the associated extensive crustal anatexis and detachment faulting reworking thoroughly the initial collisional structure of the belt. The related pervasive rejuvenation of the mantle lithosphere is proposed to be a major element to 
consider in the development of the subsequent long-term thermal subsidence of the lithosphere that controlled successor Upper Permian-Mesozoic basins such as the Paris basin (Prijac et al., 2000; Averbuch and Piromallo, 2012).

\section{Supplementary material}

Fig. S1. Multi-element spider plots. A: granite-gneiss. B: Ballons and S-Vosges vaugnerite (Vo15-08). C: Crêtes and Central Vosges vaugnerites (Vo15-01, Vo15-04, Vo15-07). Fig. S2. Wetherill Concordia plots for the dated rocks.

Fig. S3. Tera-Wasserburg Concordia plots for the dated rocks. Tab. S4. Zircon LA-ICP-MS microchemical data. A: Vo14-16 granite-gneiss. B: Vo15-01 Clefcy vaugnerite. C: Vo15-04 Barançon vaugnerite. D: Vo15-07 Habeaurupt vaugnerite. E: Vo15-08 Ballons vaugnerite.

Tab. S5. Zircon LA-ICP-MS isotopic U-Pb-Th data. QC: quality of concordance (cf. Tab. 1). LOD: limit of detection. A: Vo14-16 granite-gneiss. B: Vo15-01 Clefcy vaugnerite. C: Vo15-04 Barançon vaugnerite. D: Vo15-07 Habeaurupt vaugnerite. E: Vo15-08 Ballons vaugnerite.

The Supplementary material is available at https://www.bsgf. fr/ $10.1051 /$ bsgf/2020027/olm.

Acknowledgements. This work was funded by the IREPSE federative research program of the University of Lille and by own scientific funds of the LGCgE. It benefitted also from the support of the INSU-SYSTER program of the CNRS (DELAM project, PI O.A). J.-F. Moyen, J. Von Hunen, A. Gébelin, L. Beccaletto, G. Mohn, D. Frizon de Lamotte and F. Roure are particularly acknowledged for the fruitful discussions on the lithospheric delamination process held in the frame of the DELAM project workshops. Philippe Recourt is greatly thanked for his support during the SEM sessions. Jane Scarrow kindly provided N-MORB and chondrite references used in her 2008 paper, and Anne-Sophie Tabaud is thanked for information on the GG4 sample. The authors are very thankful to Cyrille Delangle (Terrae Genesis) for presenting various interesting outcrops of the Vosges Massif. Constructive reviews by J.Melleton and an anonymous reviewer greatly improved a first version of this article.

\section{References}

Altherr R, Kalt A. 1996. Metamorphic evolution of ultrahigh-pressure garnet peridotites from the Variscan Vosges Mts. (France). Chemical Geology 134: 27-47.

Altherr R, Henjes-Kunst F, Langer C, Otto J. 1999. Interaction between crustal-derived felsic and mantle-derived mafic magmas in the Oberkirch Pluton (European Variscides, Schwarzwald, Germany). Contributions to Mineralogy and Petrology 137: 304-322.

Altherr R, Hanel M, Schwarz WH, Wimmenauer W. 2019. Petrology and $\mathrm{U}-\mathrm{Pb}$ zircon age of the Variscan porphyroclastic Rand Granite at the southeastern margin of the Central Schwarzwald Gneiss Complex (Germany). International Journal of Earth Sciences 108: 1879-1895.

Altherr R, Holl A, Hegner E, Langer C, Kreuzer H. 2000. Highpotassium, calc-alkaline I-type plutonism in the European Variscides: northern Vosges (France) and northern Schwarzwald (Germany). Lithos 50: 51-73.
Altherr R, Soder CG. 2018. Sapphirine as a breakdown product of garnet in a Variscan UHP/HT peridotite from the Vosges Mountains (France) - An indication of near-isothermal decompression. Journal of Petrology 59: 2221-2243.

Anders E, Grevesse N. 1989. Abundances of the elements: meteoritic and solar. Geochimica et Cosmochimica Acta 53: 197-214.

André F. 1981. Un exemple de vaugnérite, cumulat d'une association gabbro-dioritique dans le massif des Ballons (Vosges méridionales, France). Comptes rendus de l'Académie des sciences. Série II 293: 445-448.

André F. 1983. Pétrologie structurale et pétrogenèse des formations plutoniques septentrionales du Massif des Ballons (Vosges, France). Unpubl. mem., thèse Université Nancy 1, Faculté des sciences, 298 p. Available at: tel.archives-ouvertes.fr/tel-01782377 (last consult: 2020/05/05).

André F, Bébien J. 1983a. Déchirures continentales et plutonisme : étude pétrologique et structurale comparée de l'association ignée de Guévguéli (Macédoine grecque) et des formations plutoniques basiques situées en bordure nord du Massif des Ballons (Vosges, France). Bulletin de la Société géologique de France 25: 291-299.

André F, Bébien J. 1983b. Minéralogie et pétrologie des cumulats gabbro-dioritiques situés en bordure septentrionale du massif des Ballons (Vosges méridionales, France) : cristallisation d'un magma basique en domaine " orogénique » intracontinental. Bulletin de minéralogie 106: 341-351.

André F, Gagny C. 1981. Proposition d'un âge namurien pour le granite porphyroïde des Ballons, témoin vosgien du plutonisme à potentialité molybdifère au Carbonifère supérieur. Congrès national des Sociétés savantes 106: 287-296.

Arnold J, Jacoby WR, Schmeling H, Schott B. 2001. Continental collision and the dynamic and thermal evolution of the Variscan orogenic crustal root-numerical models. Journal of Geodynamics 31: 273-291.

Averbuch O, Mansy J-L, Lamarche J, Lacquement F, Hanot F. 2004. Geometry and kinematics of the Boulonnais fold-and-thrust belt $(\mathrm{N}$ France): implications for the dynamics of the Northern Variscan thrust front. Geodinamica Acta 17: 163-178.

Averbuch O, Piromallo C. 2012. Is there a remnant Variscan subducted slab in the mantle beneath the Paris basin? Implications for the late Variscan lithospheric delamination process and the Paris basin formation. Tectonophysics 558-559: 70-83.

Ballèvre M, Bosse V, Ducassou C, Pitra P. 2009. Palaeozoic history of the Armorican Massif: models for the tectonic evolution of the suture zones. Comptes rendus geoscience 341: 174-201.

Bambauer HU, Kroll H, Nager HE, Pentinghaus H. 1974. FeldspatMischkristalle: eine Übersicht. Bulletin de la Société française de minéralogie et de cristallographie 97: 313-345.

Banzet G. 1987. Interactions croÛte-manteau et genèse du plutonisme subalcalin du Haut-Dauphiné occidental (massifs cristallins externes, Alpes) : vaugnérites, durbachites et granitoïdes magnésio-potassiques. Géologie alpine 63: 95-117.

Barbarin B. 1999. A review of the relationships between granitoid types, their origins and their geodynamic environments. Lithos 46: 605-626.

Barbey P, Villaros A, Marignac C, Montel J-M. 2015. Multiphase melting, magma emplacement and P-T-time path in late-collisional context: the Velay example (Massif Central, France). Bulletin de la Société géologique de France 186: 93-116.

Bell EA, Boehnke P, Barboni M, Harrison TM. 2019. Tracking chemical alteration in magmatic zircon using rare earth element abundances. Chemical Geology 510: 56-71.

Belousova EA, Griffin WL, O'Reilly SY, Fisher NI. 2002. Igneous zircon: trace element composition as an indicator of source 
rock type. Contributions to Mineralogy and Petrology 143: 602622.

Blumenfeld P, Bouchez J-L. 1988. Shear criteria in granite and migmatite deformed in the magmatic and solid states. Journal of Structural Geology 10: 361-372.

Bonin B, Azzouni-Sekkal A, Bussy F, Ferrag S. 1998. Alkali-calcic and alkaline post-orogenic (PO) granite magmatism: petrologic constraints and geodynamic settings. Lithos 45: 45-70.

Bonin B. 2004. Do coeval mafic and felsic magmas in post-collisional to within-plate regimes necessarily imply two contrasting, mantle and crustal, sources? A review. Lithos 78: 1-24.

Bourgeois O, Ford M, Diraison M, Le Carlier de Veslud C, Gerbault M, Pik R, et al. 2007. Separation of rifting and lithospheric folding signatures in the NW-Alpine foreland. International Journal of Earth Sciences 96: 1003-1031.

Boutin R, Montigny R, Thuizat R. 1995. Chronologie K-Ar et 39Ar40 du métamorphisme et du magmatisme des Vosges. Comparaison avec les massifs varisques avoisinants. Géologie de la France (1): $3-25$.

Burg JP, Van den Driessche J, Brun JP. 1994. Syn-to post-thickening extension in the Variscan Belt of Western Europe: modes and structural consequences. Géologie de la France (3): 33-51.

Bussy F, Delitroz D, Fellay R, Hernandez J. 1998. The Pormenaz monzonite (Aiguilles-Rouges, Western Alps): an additional evidence for a 330 Ma-old magnesio-potassic magmatic suite in the Variscan Alps. Schweizerische mineralogische und petrographische Mitteilungen 78: 193-194.

Camboly J. 1966. Étude pétrographique et géochimique des granites de la région du Vic-Habeauru (Vosges) et de leurs enclaves. Unpubl. mem., Thèse Faculté des Sciences, Université de Nancy, $87 \mathrm{p}$.

Camboly J, Hameurt J, Rocci G. 1967. Relations génétiques entre vaugnérite et kersantite et hypothèse originale sur la genèse des lamprophyres des Vosges. Comptes rendus de l'Académie des sciences. Série D 264: 25-28.

Carasco B. 1989. Lacustrine sedimentation in a Permian intermontane basin: the Villé graben (Vosges, France). Paleogeography, Paleoclimatology, Paleoecology 70: 179-186.

Caruba R, Turco G. 1971. Mise au point sur la notation des faces du zircon. Élaboration d'une méthode d'indexation rapide des faces des zircons accessoires des roches par utilisation d'abaques. Bulletin de la Société française de minéralogie et de cristallographie 94: 427-436.

Chemenda AI, Mattauer M, Bokun A. 1996. Continental subduction and a mechanism for exhumation of high-pressure metamorphic rocks: new modelling and field data from Oman. Earth and Planetary Science Letters 143: 172-182.

Chen F, Todt W, Hann HP. 2003. Zircon and garnet geochronology of eclogites from the Moldanubian zone of the Black Forest, Germany. Journal of Geology 111: 207-222.

Chew DM, Petrus JA, Kamber BS. 2014. U-Pb LA-ICPMS dating using accessory mineral standards with variable common $\mathrm{Pb}$. Chemical Geology 363: 185-199.

Condamine P, Médard E. 2014. Experimental melting of phlogopitebearing mantle at $1 \mathrm{GPa}$ : implications for potassic magmatism. Earth and Planetary Science Letters 397: 80-92.

Costa S, Rey P. 1995. Crustal rejuvenation and growth during postthickening collapse: insights from a crustal cross-section through a variscan metamorphic core complex. Geology 23: 905-908.

Couzinié S, Laurent O, Moyen J-F, Zeh A, Bouilhol P, Villaros A. 2016. Post-collisional magmatism: crustal growth not identified by zircon Hf-O isotopes. Earth and Planetary Science Letters 456: 182-195.
Couzinié S, Moyen J-F, Villaros A, Paquette J-L, Scarrow JH, Marignac C. 2014. Temporal relationships between Mg-K mafic magmatism and catastrophic melting of the Variscan crust in the southern part of Velay Complex (Massif Central, France). Journal of Geosciences 59: 69-86.

Debon F, Guerrot C, Ménot R-P, Vivier G, Cocherie A. 1998. Late Variscan granites of the Belledonne massif (French Western Alps): an Early Visean magnesian plutonism. Schweizerische mineralogische und petrographische Mitteilungen 78: 67-85.

Debon F, Lemmet M. 1999. Evolution of $\mathrm{Mg} / \mathrm{Fe}$ ratios in Late Variscan plutonic rocks from the external crystalline massif of the Alps (France, Italy, Switzerland). Journal of Petrology 40: 11511185 .

DeCelles PG, Robinson DM, Zandt G. 2002. Implications of shortening in the Himalayan fold-thrust belt for uplift of the Tibetan plateau. Tectonics 21: 1062. https://doi.org/10.1029/ $2001 \mathrm{TC} 001322$.

Delesse A. 1851. Sur la composition minéralogique et chimique des roches des Vosges. Annales des mines 19: 149-183. Available at: patrimoine.mines-paristech.fr/items/viewer/103\#page/Image +74/ mode/2up (last consult: 2020/05/05).

Donsimoni M. 1981. Le bassin houiller lorrain. Synthèse géologique. Mémoires du Bureau de recherches géologiques et minières 117, $102 \mathrm{p}$.

Durand M. 2014. Le bassin permien de Saint-Dié. In: Gély J-P, Hanot F, eds. Le bassin parisien, un nouveau regard sur la géologie. Paris: Association des géologues du Bassin, $139 \mathrm{p}$.

Dupuis NE, Braid JA, Brendan Murphy J, Shail R, Archibald DA, Nance D. 2015. ${ }^{40} \mathrm{Ar} /{ }^{39} \mathrm{Ar}$ phlogopite geochronology of lamprophyre dykes in Cornwall, UK: new age constraints on Early Permian post-collisional magmatism in the Rhenohercynian Zone, SW England. Journal of the Geological Society, London 172: 566575.

Echtler HP, Chauvet A. 1992. Carboniferous convergence and subsequent crustal extension In the southern Schwarzwald (SW Germany). Geodinamica Acta 5: 37-49.

Edel JB, Fluck P. 1989. The Upper Rhenish Shield basement (Vosges, upper Rhinegraben and Schwarzwald): main structural features deduced from magnetic, gravimetric and geological data. Tectonophysics 169: 303-316.

Edel J-B, Schneider J-L. 1995. The late Carboniferous to early Triasic geodynamic evolution of Variscan Europe in the light of magnetic overprints in Early Permian rhyolites from the Northern Vosges (France) and central Black Forest (Germany). Geophysical Journal International 122: 858-876

Edel JB, Schulmann K. 2009. Geophysical constraints and model of the "Saxothuringian and Rhenohercynian subductions-magmatic arc system" in NE France and SW Germany. Bulletin de la Société géologique de France 180: 545-558.

Edel JB, Schulmann K, Skrzypek E, Cocherie A. 2013. Tectonic evolution of the European Variscan belt constrained by paleomagnetic, structural and anisotropy of magnetic susceptibility data from the Rhenohercynian magmatic arc (Northern Vosges, Eastern France). Journal of the Geological Society, London 170: 785-804.

Eisbacher GH, Lüschen E, Wickert F. 1989. Crustal-scale thrusting and extension in the Hercynian Schwarzwald and Vosges, central Europe. Tectonics 8: 1-21.

Eisele J, Gertisser R, Montenari M. 2000. Geochemistry and provenance of Devono-Carboniferous volcano-sedimentary sequences from the Southern Vosges Basin and the geodynamic implications for the Western Moldanubian Zone. In: Franke W, Haak V, Oncken O, Tanner D, eds. Orogenic processes: 
quantification and modelling in the Variscan Belt. Geological Society, London, Special Publications 179: 433-444.

Exley CS, Stone M, Floyd PA. 1983. Composition and petrogenesis of the Cornubian granite batholith and post-orogenic volcanic rocks in southwest England. In: Hancock PL, ed. The Variscan Fold belt in the British Isles. Bristol: Adam Higer Ltd, pp. 153-177.

Faryad SW, Kachlyk V. 2013. New evidence of blueschist facies rock and their geotectonic implication for Variscan suture(s) in the Bohemian Massif. Journal of Metamorphic Geology 31: 63-82.

Faure M. 1995. Late orogenic carboniferous extensions in the Variscan French Massif Central. Tectonics 14: 132-153.

Faure M, Bé Mézème E, Cocherie A, Rossi P, Chemenda A, Boutelier D. 2008. Devonian geodynamic evolution of the Variscan Belt, insights from the French MassifCentral and Massif Armoricain. Tectonics 27: 27, TC2005. https://doi.org/2010.1029/2007TC002115.

Faure M, Lardeaux J-M, Ledru P. 2009. A review of the pre-Permian geology of the Variscan French Massif Central. Comptes rendus géoscience 341: 202-213.

Femenias O, Coussaert N, Berger J, Mercier J-C, Demaiffe D. 2004. Metasomatism and melting history of a Variscan lithospheric mantle domain: evidence from the Puy Beaunit xenoliths (French Massif Central). Contributions to Mineralogy and Petrology 148: 13-28.

Finger F, Gerdes A, Rene M, Riegler G. 2009. The Saxo-Danubian Granite belt: magmatic response to post-collisional delamination of mantle lithosphere below the south-western sector of the Bohemian massif (Variscan orogen). Geologica Carpathica 60: 205-212.

Fluck P. 1980. Métamorphisme et magmatisme dans les Vosges moyennes d'Alsace, contribution à l'histoire de la chaîne varisque. Sciences géologiques (bulletin et mémoires), Strasbourg 62: 1-247.

Fluck P, Edel J-B, Gagny C, Montigny R, Piqué A, Schneider J-L, et al. 1989. Carte synthétique et géotraverse N-S de la chaîne varisque des Vosges (France). Synthèse des travaux effectués depuis deux décennies. Comptes rendus de l'Académie des sciences. Série II 309: 907-912.

Foley S. 1992. Vein-plus-wall-rock melting mechanisms in the lithosphere and the origin of potassic alkaline magmas. Lithos 28: 435-453.

Förster MW, Prelevic D, Buhre S, Mertz-Kraus R, Foley SF. 2019. An experimental study of the role of partial melts of sediments versus mantle melts in the sources of potassic magmatism. Journal of Asian Earth Sciences 177: 76-88.

Franke W. 2000. The mid-European segment of the Variscides: tectonostratigraphic units, terrane boundaries and plate tectonic evolution. In: Franke W, Haak V, Oncken O, Tanner D, eds. Orogenic processes: quantification and modelling in the Variscan Belt. Geological Society, London, Special Publications 179: 35-61.

Franke W, Stein E. 2000. Exhumation of high-grade rocks in the Saxo-Thuringian Belt: geological constraints and geodynamic concepts. Geological Society, London, Special Publications 179: 337-354.

Franke W. 2006. The Variscan orogen in Central Europe: construction and collapse. Geological Society, London, Memoirs 32: 333-343.

Franke W, Cocks LRM, Torsvik TH. 2017. The Palaeozoic Variscan oceans revisited. Gondwana Research 48: 257-284.

Furman T, Graham D. 1999. Erosion of lithospheric mantle beneath the East African Rift system: geochemical evidence from the Kivu volcanic province. Lithos 48: 237-262.

Gagny C. 1968. Pétrogenèse du Granite des Crêtes, Vosges méridionales - France. Thèse Fac. Sci. Univ. Nantes, 548 p. Available at: orage. univ- lorraine. $\mid \mathrm{fr} /$ files/original/0ed0aab7e3ef1852f88f6696e12631bc. pdf (last consult: 2020/05/05).

Gagny C. 1978. Vaugnérites et durbachites sont des cumulats de magma granitique (l'exemple du magma des Crêtes, Vosges). Comptes rendus de l'Académie des sciences. Série D 287: 1361-1364.
Gardien V, Lardeaux J-M, Ledru P, Allemand P, Guillot S. 1997. Metamorphism during late orogenic extension: insights from the French Variscan Belt. Bulletin de la Société géologique de France 168: 271-286.

Gao M, Xu H, Zhang J, Foley SF. 2019. Experimental interaction of granitic melt and peridotite at $1.5 \mathrm{GPa}$ : implications for the origin of post-collisional K-rich magmatism in continental subduction zones. Lithos 350-351: 105241.

Gayk T, Kleinschrodt R. 2000. Hot contacts of garnet peridotites in middle/upper crustal levels: new constraints on the nature of the late Variscan high-T/low-P event in the Moldanubian(Central Vosges/NE France). Journal of Metamorphic Geology 18: 293-305.

Gerdes A, Worner G, Finger F. 2000. Hybrids, magma mixing and enriched mantle melts in post-collisional Variscan granitoids: the Rastenberg Pluton, Austria. In: Franke W, Haak V, Oncken O, Tanner D, eds. Orogenic processes: quantification and modelling in the Variscan Belt. Geological Society, London, Special Publications 179: 415-431.

Gray R, Pysklywec RN. 2012. Geodynamic models of mature continental collision: evolution of an orogen from lithospheric subduction to continental retreat/delamination. Journal of Geophysical Resarch 117: B03408. https://doi.org/10.1029/ 2011JB008692.

Grimes CB, Wooden JL, Cheadle MJ, John BE. 2015. "Fingerprinting" tectono-magmatic provenance using trace elements in igneous zircon. Contributions to Mineralogy and Petrology 170: 46.

Guillaume B, Martinod J, Espurt N. 2009. Variations of slab dip and overriding plate tectonics during subduction: insights from analogue modelling. Tectonophysics 463: 167-174.

Guillong M, Meier DL, Allan MM, Einrich CA, Yardley BWD. 2008. SILLS: a Matlab-based program for the reduction of Laser Ablation ICP-MS data of homogeneous materials and inclusions. Mineralogical Association of Canada Short Course 40, Vancouver, BC: 328-333.

Guillot F, Desmons J, Ploquin A. 1993. Lithostratigraphy and geochemical composition of the Mt. Pourri volcanic basement, Middle Penninic W-Alpine zone, France. Schweizerische mineralogische und petrographische Mitteilungen 73: 319-334.

Hameurt J. 1966. Idées nouvelles sur la géologie des terrains cristallophylliens des Vosges moyennes lorraines. Comptes rendus de l'Académie des sciences. Série D 263: 1928-1931.

Hameurt J. 1970. Les terrains cristallins et cristallophylliens du versant occidental des Vosges moyennes. Mémoires du service de la carte géologique d'Alsace et de Lorraine 26: 402 p.

Hegner E, Chen F, Hann HP. 2001. Chronology of basin closure and thrusting in the internal zone of the Variscan belt in the Schwarzwald, Germany: evidence from zircon ages, trace element geochemistry, and Nd isotopic data. Tectonophysics 332: 169-184.

Hegner E, Kölbl-Ebert M, Loeschke J. 1998. Post-collisional Variscan lamprophyres (Black Forest, Germany): ${ }^{40} \mathrm{Ar} /{ }^{39} \mathrm{Ar}$ phlogopite dating, $\mathrm{Nd}, \mathrm{Pb}, \mathrm{Sr}$ isotope, and trace element characteristics. Lithos 45: 395-411.

Henk A. 1993. Late orogenic evolution in the Variscan Internides: the Saar-Nahe Basin, southwest Germany. Tectonophysics 223: 273-290.

Henk A. 1997. Gravitational orogenic collapse vs plate-boundary stresses: a numerical modelling approach to the Permo-Carboniferous evolution of Central Europe. Geologische Rundschau 86: 39-55.

Henk A, von Blankenburg F, Finger F, Schaltegger U, Zulauf G. 2000. Syn-convergent high-temperature metamorphism and magmatism in the Variscides: a discussion of potential heat sources. In: Franke W, Haak V, Oncken O, Tanner D, eds. Orogenic processes: quantification and modelling in the Variscan Belt. Geological Society, London, Special Publications 179: 387-399. 
Hofmann AW. 1988. Chemical differentiation of the Earth: the relationship between mantle, continental crust, and oceanic crust. Earth and Planetary Science Letters 90: 297-314.

Holub FV. 1997. Ultrapotassic plutonic rocks of the Durbachite Series in the Bohemian Massif: petrology, geochemistry and petrogenetic interpretation. J. Geol. Sci, Economic Geol. Mineralogy 31: 5-26.

Hoth S, Kuskowski N, Oncken O. 2008. Distant effects in bivergent orogenic belts - How retro wedge erosion triggers ressource formation in pro-foreland basins. Earth and Planetary Science Letters 273: 28-37.

Houseman G, Molnar P. 2001. Mechanisms of lithospheric rejuvenation associated with continental orogeny. In Miller JA, Holdsworth REE, Buick IS, Hand M. eds.Continental reactivation and reworking. Geological Society, London, Special Publications 184: 13-38.

Jackson SE, Pearson NJ, Griffin WL, Belousova EA. 2004. The application of laser ablation-inductively coupled plasma-mass spectrometry to in situ U-Pb zircon geochronology. Chemical Geology 211: 47-69.

Janousek V, Farrow CM, Erban V. 2006. Interpretation of whole-rock geochemical data in igneous geochemistry: introducing geochemical data toolkit (GCDkit). Journal of Petrology 47: 1255-1259.

Janousek V, Holub FV. 2007. The causal link between HP-HT metamorphism and ultrapotassic magmatism in collisional orogens: case study from the Moldanubian Zone of the Bohemian Massif. Proceedings of the Geologists' Association 118: 75-86.

Janousek V, Lewa O, Schulmann K, Maierova P. 2012. What drives remelting of thickened continental crust in the Bohemian Massif? Géologie de la France 2012-1: 130-131.

Janousek V. 2019. Variscan odyssey of the Bohemian Massif and the related plutonic activity. Geologica Carpathica 70: 50-53.

Jung J, Roques M. 1952. Introduction à l'étude zonéographique des formations cristallophylliennes. Bulletin du service de la carte géologique de la France 50: 1-64.

Kawabata H, Shimura T. 2019. Three-dimensional visualization of ternary prisms (T-prism): development of a spreadsheet-based tool for Earth and material sciences. Journal of Mineralogical and Petrological Sciences 114: 142-148.

Kirkland CL, Smithies RH, Taylor RJM, Evans N, McDonald B. 2015. Zircon $\mathrm{Th} / \mathrm{U}$ ratios in magmatic environs. Lithos $212-215$ : 397-414.

Kratinová Z, Schulmann K, Edel J-B., Jezek J, Schaltegger U. 2007. Model of successive granite sheet emplacement in transtensional setting: integrated microstructural and anisotropy of magnetic susceptibility study. Tectonics 26: TC6003. https://doi.org/ 6010.1029/2006TC002035.

Krawczyk CM, Stein E, Choi S, Oettinger G, Schuster K, Gotze H-J, et al. 2000. Geophysical constraints on exhumation mechanisms of high-pressure rocks: the Saxo-Thuringian case between the Franconian Line and Elbe Zone. In: Franke W, Haak V, Oncken $\mathrm{O}$, Tanner D, eds. Orogenic processes: quantification and modelling in the Variscan Belt. Geological Society, London, Special Publications 179: 303-322.

Krmicek L, Romer RL, Ulrych J, Glodny J, Prelevic D. 2016. Petrogenesis of orogenic lamproites of the Bohemian massif: Sr$\mathrm{Nd}-\mathrm{Pb}-\mathrm{Li}$ isotope constraints for Variscan enrichment of ultradepleted mantle domains. Gondwana Research 35: 198-216.

Kubínová S, Faryad SW, Verner K, Schmitz M, Holub F. 2017. Ultrapotassic dykes in the Moldanubian Zone and their significance for understanding of the post-collisional mantle dynamics during Variscan orogeny in the Bohemian Massif. Lithos 272-273: 205-221. Lakhrissi MA. 1996. Pétrologie, minéralogie, géochimie du volcanisme dévono-dinantien des Vosges méridionales (France). Sa place dans le contexte géodynamique varisque. Unpubl. mem.,
Thèse Doct. Univ. Lille, 414 p. Available at: ori.univ-lille1.fr/ notice/view/univ-lille1-ori-133205 (last consult: 2020/05/12).

Lardeaux JM, Ledru P, Daniel I, Duchêne S. 2001. The Variscan French Massif Central - a new addition to the ultra-high pressure metamorphic "club": exhumation processes and geodynamic consequences. Tectonophysics 332: 143-167.

Lardeaux JM, Schulmann K, Faure M, Janousek V, Lexa O, Skrzypek E, et al. 2014. The Moldanubian Zone in the French Massif Central, Vosges/Schwarzwald, and Bohemian Massif revisited: differences and similarities. Geological Society, London, Special Publications 405: 7-43.

Latouche L, Fabriès J, Guiraud M. 1992. Retrograde evolution in the Central Vosges mountains (northeastern France): implications for the metamorphic history of high-grade rocks during the Variscan orogeny. Tectonophysics 205: 387-407.

Laurent O, Couzinié S, Zeh A, Vanderhaeghe O, Moyen J-F, Villaros A, et al. 2017. Protracted, coeval crust and mantle melting during Variscan late-orogenic evolution: U-Pb dating in the eastern French Massif Central. International Journal of Earth Sciences 106: 421-451.

Le Gall J, Doré F, Gresselin F, Pareyn C. 1989. Le magmatisme alcalin de la distension post-varisque dans le nord du Massif Armoricain : exemples des volcanites carbonifères du bassin de Carentan et des lamprophyres du Nord Cotentin. Annales de la Société géologique du Nord 108: 25-33.

Ledru P, Lardeaux J-M, Santallier D, Autran A, Quénardel J-M, Floc'H J-P, et al. 1989. Où sont les nappes dans le Massif central français ? [Where are the nappes in the French Massif central?]. Bulletin de la Société géologique de France 5(8): 605-618.

Ledru P, Courrioux G, Dallain C, Lardeaux JM, Montel JM, Vanderhaeghe O, Vitel G. 2001. The Velay dome (French Massif Central): melt generation and granite emplacement during orogenic evolution. Tectonophysics 342: 207-237.

Lefèvre C, Lakhrissi M, Schneider J-L. 1994. Les affinités magmatiques du volcanisme dinantien des Vosges méridionales (France) ; approche géochimique et interprétation. Comptes rendus de l'Académie des sciences. Série II 319: 79-86.

Lexa O, Schulmann K, Janousek V, Stipska P, Guy A, Racek M. 2011. Heat sources and trigger mechanisms of exhumation of HP granulites in Variscan orogenic root. Journal of Metamorphic Geology 29: 79-102.

Ludwig KR. 2003. ISOPLOT 3.0: a geochronological toolkit for Microsoft Excel. Berkeley Geochronology Center, Special Publication No. 4.

Magni V, Allen MB, Van Hunen J, Bouillol P. 2017. Continental underplating after slab break-off. Earth and Planetary Science Letters 474: 59-67.

Martin AM, Médard E, Righter K, Lanzirotti A. 2017. Intraplate mantle oxidation by volatile-rich silicic magmas. Lithos 292-293: 320-333.

Matte P. 1998. Continental subduction and exhumation of HP rocks in Paleozoic orogenic belts: Uralides and Variscides. Geol. Soc. Sweden (G.F.F.) 120: 209-222.

Matte P. 2001. The Variscan collage and orogeny (480-290 Ma) and the tectonic definition of the Armorica microplate: a review. Terra Nova 13: 122-128.

McDonough WF, Sun S-S. 1995. The composition of the Earth. Chemical Geology 120: 223-253.

Menant A, Jolivet L, Tuduri J, Loiselet C, Bertrand G, GuillouFrottier L. 2018. 3D subduction dynamics: a first-order parameter of the transition from copper- to gold-rich deposits in Eastern Mediterranean region. Ore Geology Reviews 94: 118-135.

Ménard G, Molnar P. 1988. Collapse of a Hercynian Plateau into a late Paleozoic European basin and range province. Nature 334: 235-237. 
Ménillet F, Fluck P, Flageollet J-C., Maïaux C, Lougnon J. 1978. Gérardmer. Notice explicative de la Carte géologique de la France à 1/50 000. Bur. Rech. Géol. Min. eds, Orléans, 341: 73 p.

Ménillet F, Coulon M, Fourquin C, Paicheler J-C., Lougnon J-M., Lettermann M. 1989. Thann. Notice explicative de la Carte géologique de la France à 1/50 000. Bur. Rech. Géol. Min. eds, Orléans 412: $137 \mathrm{p}$.

Michon G. 1987. Les vaugnérites de l'Est du Massif central français : apport de l'analyse statistique multivariée à l'étude géochimique des éléments majeurs. Bulletin de la Société géologique de France 3(8): 591-600.

Montel J-M, Weisbrod A. 1986. Characteristics and evolution of "vaugneritic magmas": an analytical and experimental approach, on the example of the Cévennes Médianes (French Massif Central). Bulletin de minéralogie 109: 575-587.

Montenari M. 1999. Calciclastic turbidites from the Southern Vosges basin (Central Variscan Belt): reconstruction of a lost Carboniferous Carbonate platform. Journal of Conference Abstracts EUG 10 (4): 742.

Moore VM, Wiltscko DV. 2004. Syncollisional delamination and tectonic wedge development in convergent orogens. Tectonics 23: TC2005. https://doi.org/10.1029/2002TC001430.

Morency C, Doin M-P. 2004. Numerical simulations of the mantle lithosphere delamination. Journal of Geophysical Research 109: B03410. https://doi.org/10.1029/2003JB002414.

Moyen J-F, Laurent O, Chelle-Michou C, Couzinié S, Vanderhaeghe $\mathrm{O}$, Zeh A, et al. 2017. Collision vs. subduction-related magmatism: two contrasting ways of granite formation and implications for crustal growth. Lithos 277: 154-177.

Oncken O. 1997. Transformation of a magmatic arc and an orogenic root during oblique collision and its consequences for the evolution of the European Variscides (Mid-German Crystalline Rise). Geologische Rundschau 86: 2-20.

Oncken O, Plesch A, Weber J, Ricken W, Schrader S. 2000. Passive margin detachment during arc-continent collision (Central european Variscides). In: Franke W, Haak V, Oncken O, Tanner D, eds. Orogenic processes: quantification and modelling in the Variscan Belt. Geological Society, London, Special Publications 179: 199-216.

Pagel M, Leterrier J. 1980. The subalkaline potassic magmatism of the Ballons Massif(Southern Vosges, France): Shoshonitic affinity. Lithos 13: 1-10.

Parat F, Holtz F, René M, Almeev R. 2010. Experimental constraints on ultrapotassic magmatism from the Bohemian Massif (durbachite series, Czech Republic). Contributions to Mineralogy and Petrology 159: 331-347.

Paton C, Hellstrom J, Paul B, Woodhead J, Hergt J. 2011. Iolite: freeware for the visualisation and processing of mass spectrometric data. Journal of Analytical Atomic Spectrometry 26: 2508-2518.

Petrini, K, Burg JP. 1998. Relationship between deformation, plutonism and regional metamorphism in the Markstein area (southern Vosges). Géologie de la France 1998: 13-23.

Pettke T, Oberli F, Audétat A, Guillong M, Simon AC, Hanley JJ, et al. 2012. Recent developments in element concentration and isotope ratio analysis of individual fluid inclusions by laser ablation single and multiple collector ICP-MS. Ore Geology Reviews 44: 10-38.

Piqué A, Fluck P, Schneider J-L, Whitechurch H. 1994. The Vosges Massif. In: Keppie JD, Chantraine J, Rolet J, Santallier DS, Piqué A, eds. Pre-Mesozoic geology in France and related areas. Berlin Heidelberg: Springer-Verlag, pp. 416-425.

Prijac C, Doin MP, Gaulier JM, Guillocheau F. 2000. Subsidence of the Paris Basin and its bearing on the late Variscan lithosphere evolution: a comparison between Plate and Chablis models Tectonophysics 323: 1-38.

Pupin J-P. 1980. Zircon and granite petrology. Contributions to Mineralogy and Petrology 73: 207-220.

Rey P, Burg J-P, Lardeaux J-M, Fluck P. 1989. Évolutions métamorphiques contrastées dans les Vosges orientales : témoins d'un charriage dans la chaîne varisque. Comptes rendus de l'Académie des sciences. Série II 309: 815-821.

Rey P, Burg J-P, Caron J-M. 1991. Tectonique extensive ductile et plutonisme viséo-namurien dans les Vosges. Comptes rendus de l'Académie des sciences. Série II 312: 1609-1616.

Ricken W, Shrader S, Oncken O, Plesch A. 2000. Turbidite basin and mass dynamics related to orogenic wedge growth; the RhenoHercynian case. In: Franke W, Haak V, Oncken O, Tanner D, eds. Orogenic processes: quantification and modelling in the Variscan Belt. Geological Society, London, Special Publications 179: 257-280.

Rossi P. 1986. Organisation et genèse d'un grand batholite orogénique, le batholite calco-alcalin de la Corse. Thèse Univ. Toulouse, Documents du BRGM 107, 292 p.

Rossi P, Oggiano G, Cocherie A. 2009. A restored section of the "southern Variscan realm" across the Corsica-Sardinia microcontinent. Comptes rendus géoscience 341: 224-238.

Rubatto D. 2002. Zircon trace element geochemistry: partitioning with garnet and the link between $\mathrm{U}-\mathrm{Pb}$ ages and metamorphism. Chemical Geology 184: 123-138.

Sabatier H. 1980. Vaugnérites et granites : une association particulière de roches grenues. Bulletin de minéralogie 103: 507-522.

Sabatier H. 1991. Vaugnerites: special lamprophyre-derived mafic enclaves in some Hercynian granites from Western and Central Europe. In: Didier J, Barbarin B, eds. Enclaves and Granite Petrology. Amsterdam: Elsevier, pp. 63-81.

Sawyer EW. 2008. Atlas of migmatites. The Canadian Mineralogist Special Publication. Canadian Science Publishing eds, 389 p.

Scarrow JH, Bea F, Montero P, Molina JF. 2008. Shoshonites, vaugnerites and potassic lamprophyres: similarities and differences between 'ultra'-high-K rocks. Earth and Environmental Science Transactions of the Royal Society of Edinburgh 99: 159-175.

Scarrow JH, Bea F, Montero P, Molina JF, Vaughan APM. 2006. A precise late Permian ${ }^{40} \mathrm{Ar} /{ }^{39} \mathrm{Ar}$ age for Central Iberian camptonitic lamprophyres. Geologica Acta 4: 451-459.

Scarrow JH, Molina JF, Bea F, Montero P, Vaughan APM. 2011. Lamprophyre dikes as tectonic markers of late orogenic transtension timing and kinematics: a case study from the Central Iberian Zone. Tectonics 30: TC4007. https://doi.org/10.1029/ 2010 TC002755.

Schäfer F, Oncken O, Kemnitz H, Romer RL. 2000. Upper-plate deformation during collisional orogeny: a case study from the German Variscides (Saxo-Thuringian Zone). In: Franke W, Haak V, Oncken O, Tanner D, eds. Orogenic processes: quantification and modelling in the Variscan Belt. Geological Society, London, Special Publications 179: 281-302.

Schaltegger U, Corfu F. 1992. The age and source of late Hercynian magmatism in the central Alps: evidence from precise $\mathrm{U}-\mathrm{Pb}$ ages and initial Hf isotopes. Contributions to Mineralogy and Petrology 111: 329-344.

Schaltegger U, Fanning CM, Günther D, Maurin JC, Schulman K, Gebauer D. 1999. Growth, annealing and recrystallization of zircon and preservation of monazite in high-grade metamorphism: conventional and in-situ U-Pb isotope, cathodoluminescence and microchemical evidence. Contributions to Mineralogy and Petrology 134: 186-201. 
Schaltegger U, Schneider J-L, Maurin J-C, Corfu F. 1996. Precise U$\mathrm{Pb}$ chronometry of $345-340 \mathrm{Ma}$ old magmatism related to synconvergence extension in the Southern Vosges/Central Variscan Belt. Earth and Planetary Science Letters 144: 403-419.

Schiller D, Finger F. 2019. Application of Ti-in-zircon thermometry to granite studies: problems and possible solutions. Contributions to Mineralogy and Petrology 174: 51.

Schneider J-L. 1990. Enregistrement de la dynamique varisque dans les bassins volcano-sédimentaires dévono-dinantiens. Exemple des Vosges du sud (zone moldanubienne). Unpubl. PhD Thesis, Université de Strasbourg, 222 p.

Schott B, Schmelling H. 1998. Delamination and detachment of a lithospheric root. Tectonophysics 296: 225-247.

Schulmann K, Schaltegger U, Jezek J, Thompson AB, Edel J-B. 2002. Rapid burial and exhumation during orogeny: thickening and synconvergent exhumation of thermally weakened and thinned crust (Variscan orogen in western Europe). American Journal of Science 302: 856-879.

Schulmann K, Lexa O, Janousek V, Lardeaux J-M, Edel JB. 2014. Anatomy of a diffuse cryptic suture zone: an example from the Bohemian Massif, European Variscides. Geology 42: 275-278.

Seifert T. 2008. Metallogeny and Petrogenesis of Lamprophyres in the Mid-European Variscides: Post-collisional Magmatism and Its Relationship to Late-Variscan Ore Forming Processes in the Erzgebirge (Bohemian Massif). IOS Press, 303 p.

Siebel W, Eroglu S, Shang C, Rohrmuller J. 2012. Zircon geochronology and $\mathrm{Sr}-\mathrm{Nd}$ isotope geochemistry of two Variscan granitoids from the Odenwald-Spessart crystalline complex (MidGerman Crystalline Rise). Mineralogy and Petrology 105: 187-200.

Skrzypek E, Tabaud A-S, Edel J-B, Schulmann K, Cocherie A, Guerrot C, et al. 2012a. The significance of Late Devonian ophiolites in the Variscan orogen: a record from the Vosges Klippen Belt. International Journal of Earth Sciences 101: 951-972.

Skrzypek E, Stípská P, Cocherie A. 2012b. The origin of zircon and the significance of $\mathrm{U}-\mathrm{Pb}$ ages in high-grade metamorphic rocks: a case study from the Variscan orogenic root (Vosges Mountains, NE France). Contributions to Mineralogy and Petrology 164: 935-957.

Skrzypek E, Schulmann K, Tabaud A-S, Edel J-B. 2014. Palaeozoic evolution of the Variscan Vosges Mountains. Geological Society, London, Special Publications 405: 45-75.

Sláma J, Kosler J, Condon DJ, Crowley JL, Gerdes A, Hanchar JM, et al. 2008. Plesovice zircon - A new natural reference material for $\mathrm{U}-\mathrm{Pb}$ and Hf isotopic microanalysis. Chemical Geology 249: 1-35.

Soder CG, Romer RL. 2018. Post-collisional potassic-ultrapotassic magmatism of the Variscan Orogen: implications for mantle metasomatism during continental subduction. Journal of Petrology 59: 1007-1034.

Solgadi F, Moyen J-F, Vanderhaeghe O, Sawyer EW, Reisberg L. 2007. The role of crustal anatexis and mantle-derived magmas in the genesis of synorogenic Hercynian granites of the Livradois area, French Massif Central. Canadian Mineralogist 45: 581-606.

Stollhofen H. 1998. Facies architecture variations and seismogenic structures in the Carboniferous-Permian Saar-Nahe Basin (SW Germany): evidence for extension-related transfer fault activity. Sedimentary Geology 119: 47-83.

Sun S-S, McDonough WF. 1989. Chemical and isotopic systematics of oceanic basalts: implications for mantle composition and processes. Geological Society, London, Special Publications 42: 313-345.

Sunagawa I. (1981). Characteristics of crystal growth in nature as seen from the morphology of mineral crystals. Bulletin de minéralogie 104: 81-87.
Tabaud A-S. 2012. Le magmatisme des Vosges: conséquence des subductions paléozoïques (datation, pétrologie, géochimie, ASM). Thèse Université de Strasbourg NNT: 2012STRAH003: 227 p. Available at: tel.archives-ouvertes.fr/tel-00755354 (last consult: 2020/05/05).

Tabaud A-S, Whitechurch H, Rossi P, Schulmann K, Guerrot C, Cocherie A. 2014. Devonian-Permian magmatic pulses in the northern Vosges Mountains (NE France): result of continuous subduction of the Rhenohercynian Ocean and Avalonian passive margin. Geological Society, London, Special Publications 405: 197-223.

Tabaud A-S, Janouzek V, Skrzypek E, Schulmann K, Rossi P, Whitechurch $\mathrm{H}$, et al. 2015. Chronology, petrogenesis and heat sources for successive Carboniferous magmatic events in the Southern-Central Variscan Vosges Mts (NE France). Journal of the Geological Society, London 172: 87-102.

Théobald N, Thiébaut J, Bernatzky M. 1974. Giromagny. Notice explicative de la Carte géologique de la France à 1/50 000. Bur. Rech. Géol. Min. eds 411: 23 p.

Turpin L, Velde D, Pinte, G. 1988. Geochemical comparison between minettes and kersantites from the Western European Hercynian orogen: trace element and $\mathrm{Pb}-\mathrm{Sr}-\mathrm{Nd}$ isotope constraints on their origin. Earth and Planetary Science Letters 87: 73-86.

Vaida M, Hann HP, Sawatzki G, Frisch W. 2004. Ordovician and Silurian protolith ages of metamorphosed clastic sedimentary rocks from the southern Schwarzwald, SW Germany: a palynological study and its bearing on the Early Palaeozoic geotectonic evolution. Geological Magazine 141: 629-643.

von Eller J-P, Fluck P, Hameurt J. 1970. Carte géologique des Vosges moyennes, partie centrale et partie orientale. Bulletin du Service de la carte géologique d'Alsace et de Lorraine 23: 29-50. Available at: https://www.persee.fr/doc/sgeol_0037-2560_1970 num_23_1_1366 (last consult:2018/12/26).

von Eller J-P, Fluck P, Hameurt J, Ruhland M. 1972. Présentation d'une carte structurale du socle vosgien. Sciences Géologiques. Bulletin 25: 3-20. Available at: https://www.persee.fr/doc/ sgeol_0302-2692_1972_num_25_1_1401 (last consult:2018/12/30). von Raumer JF, Finger F, Vesela P, Stampfli GM. 2013. DurbachitesVaugnerites-a geodynamic marker in the Central European Variscan orogen. Terra Nova 26: 85-95.

von Seckendorff V, Arz C, Lorenz V. 2004a. Magmatism of the late Variscan intermontane Saar-Nahe Basin (Germany): a review. Geological Society, London, Special Publications 223: 361-391.

von Seckendorff V, Timmerman MJ, Kramer W, Wrobel P. 2004b. New ${ }^{40} \mathrm{Ar} /{ }^{39} \mathrm{Ar}$ ages and geochemistry of late Carboniferous-early Permian lamprophyres and related volcanic rocks in the Saxothuringian Zone of the Variscan Orogen (Germany). Geological Society, London, Special Publications 223: 335-359.

Wang X, Griffin WL, Chen J, Huang P, Li X. 2011. U and Th contents and $\mathrm{Th} / \mathrm{U}$ ratios of zircon in felsic and mafic magmatic rocks: improved zircon-melt distribution coefficients. Acta Geologica Sinica - English Edition 85: 164-174.

Watson EB, Harrison TM. 1983. Zircon saturation revisited: temperature and composition effects in a variety of crustal magma types. Earth and Planetary Science Letters 64: 295-304.

Watson EB, Wark DA, Thomas JB. 2006. Crystallization thermometers for zircon and rutile. Contributions to Mineralogy and Petrology 151: 413-433.

Whitney DL, Evans BW. 2010. Abbreviations for names of rockforming minerals. American Mineralogist 95: 185-187.

Wickert F, Eisbacher GH. 1988. Two-sided Variscan thrust tectonics in the Vosges Mountains, northeastern France. Geodinamica Acta 2: 101-120. 
Wiebe RA, Collins WJ. 1998. Depositional features and stratigraphic sections in granitic plutons: implications for the emplacement and crystallization of granitic magma. Journal of Structural Geology 20: $1273-1289$.
Zeitlhofer H, Grasemann B, Petrakakis K. 2016. Variscan potassic dyke magmatism of durbachitic affinity at the southern end of the Bohemian Massif (Lower Austria). International Journal of Earth Sciences 105: 1175-1197.

Cite this article as: Guillot F, Averbuch O, Dubois M, Durand C, Lanari P, Gauthier A. 2020. Zircon age of vaugnerite intrusives from the Central and Southern Vosges crystalline massif (E France): contribution to the geodynamics of the European Variscan belt, BSGF - Earth Sciences Bulletin 191: 26. 